\title{
MASTER
}

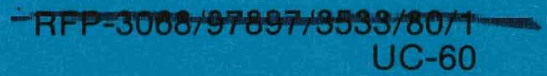

DOE/DP/O3533-T2

\section{Financial Problems Facing the Manufacturers of Small Wind Energy Conversion Systems}

\section{FINAL REPORT}
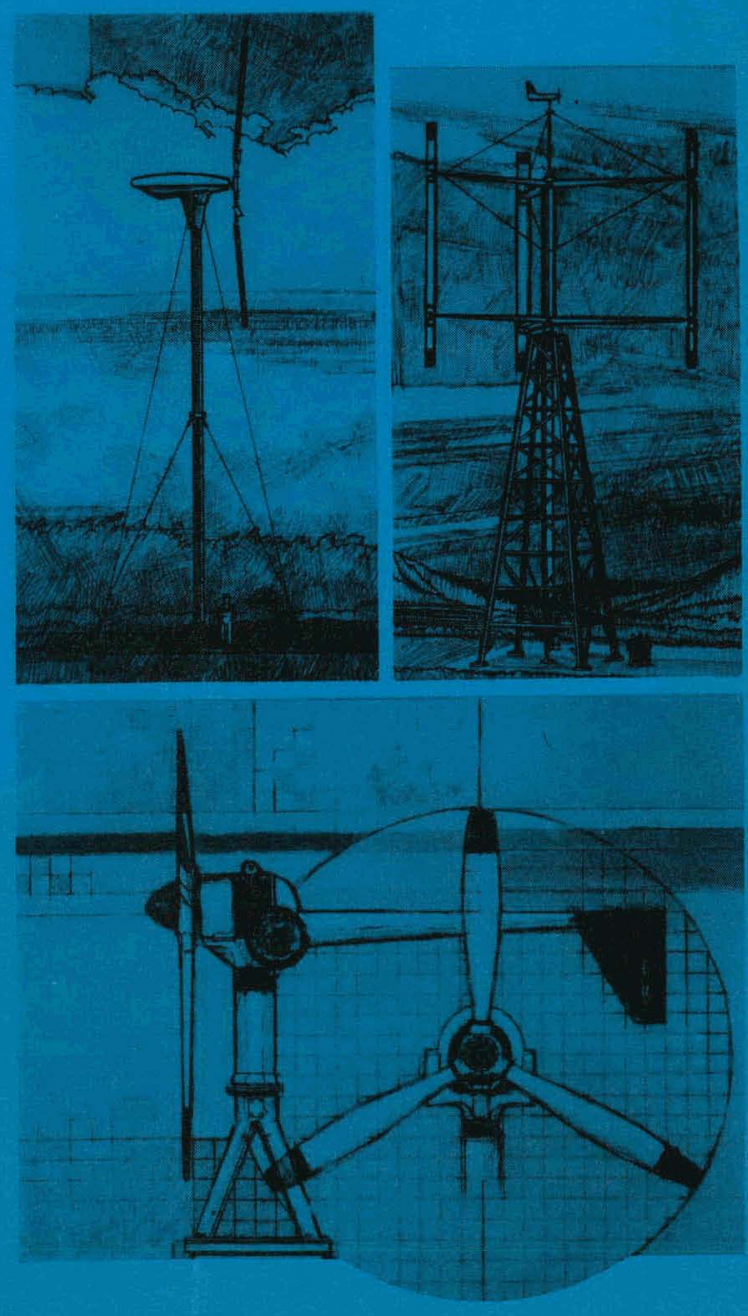

\author{
November 1979
}

\section{THOMAS G. BOLLE}

\section{Prepared by}

JDB \& Company

1629 K Street, N.W.

Suite 700

Washington, DC 20006

for

Rockwell International Corporation

Energy Systems Group

Rocky Flats Plant

Wind Systems Program

P.O. Box 464

Golden, Colorado 80401

Agreement No. PF-97897L

As Part of the

UNITED STATES DEPARTMENT OF ENERGY

DIVISION OF DISTRIBUTED SOLAR TECHNOLOGY

FEDERAL WIND ENERGY PROGRAM

Contract No. DE-ACO4-76DPO3533 


\section{DISCLAIMER}

This report was prepared as an account of work sponsored by an agency of the United States Government. Neither the United States Government nor any agency Thereof, nor any of their employees, makes any warranty, express or implied, or assumes any legal liability or responsibility for the accuracy, completeness, or usefulness of any information, apparatus, product, or process disclosed, or represents that its use would not infringe privately owned rights. Reference herein to any specific commercial product, process, or service by trade name, trademark, manufacturer, or otherwise does not necessarily constitute or imply its endorsement, recommendation, or favoring by the United States Government or any agency thereof. The views and opinions of authors expressed herein do not necessarily state or reflect those of the United States Government or any agency thereof. 


\section{DISCLAIMER}

Portions of this document may be illegible in electronic image products. Images are produced from the best available original document. 


\section{DISCLAIMER}

This report was prepared as an account of work sponsored by the United States government. Neither the United States nor the United States Department of Energy, nor any of their employees, makes any warranty, express or implied, or assumes any legal liability or responsibility for the accuracy, completeness, or usefulness of any information, apparatus, product, or process disclosed, or represents that its use would not infringe privately owned rights. Reference herein to any specific commercial product, process or service by trade name, mark, manufacturer, or otherwise, does not necessarily constitute or imply its endorsement, recommendation, or favoring by the United States government or any agency thereof. The views and opinions of authors expressed herein do not necessarily state or reflect those of the United States government or any agency thereof.

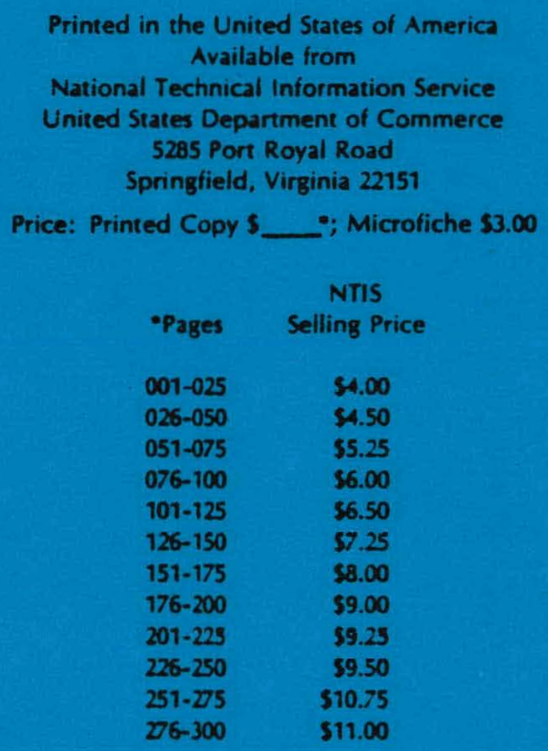


FINANCIAL PROBLEMS

FACING THE MANUFACTURERS OF

SMALL WIND ENERGY CONVERSION SYSTEMS

Final Report

November 1979

Thomas G. Bolle

Prepared by

JDB \& Company

$1629 \mathrm{~K}$ Street, N.W.

Suite 700

Washington, DC 20006

for

Rockwell International Corporation

Energy Systems Group

Rocky Flats Plant

Wind Systems Program

P.0. Box 464

Golden, CO 80401

Agreement No. PF-97897L

As Part of the

UNITED STATES DEPARTMENT OF ENERGY DIVISION OF DISTRIBUTED SOLAR ENERGY TECHNOLOGY FEDERAL WIND ENERGY PROGRAM

Contract No. DE-ACO4-76DP03533 


\section{ABSTRACT}

The financial barriers faced by the manufacturers of small wind energy conversion systems (SWECS) are assessed and found to be similar to those faced by other start up businesses. However, these problems are found to be aggravated by the high expectations for accelerated SWECS industry growth in the face of moderate government support and lack of investment capital. The underlying conditions of Timited SWECS entrepreneur business experience, the highly competitive venture capital market, the inability of existing financial institutions to aid infant businesses and public unawareness of SWECS are reviewed. Specific manufacturer-oriented recommendations and federal, state and regulatory policyoriented recommendations are made. In addition, the dynamics of the SWECS commercialization process are assessed and the variety of financial institutions playing a role in this process is detailed. Issues related to inflation, tax policy, regulation and federal R\&D procurement policies are analyzed. 
This study has clearly shown that, to a significant extent, the financial barriers faced by Small Wind Energy Conversion Systems (SWECS) manufacturers fall into two distinct categories:

- The problems normally associated with start up businesses--... capital, management, personnel, cash flow, etc.

0

Unfulfilled expectations that are a result of the discrepancy between what the federal government states is the potential. SWECS role in meeting the nation's energy needs and the scope of federal actions designed to achieve such aspirations; as perceived by SWECS manufacturers, financial experts and the buyer public.

The harsh reality is that, for several reasons, most of the existing SWECS will not succeed in the market place. In this case the marketplace is not defined as a potential based on climate, land use and "if this, then that" considerations. Rather, the marketplace is defined in terms of the hard and fast realities of who today wants to buy the products and who is available to sell the produts.

The typical entrepreneur in this area is generally highly trained and. conceptually oriented but evidences a significant weakness in his capacity. to deal with managerial and financial issues. Today!s business environment is tough, with few opportunities for access to significant capital and ever increasing legal pitfalls if attempts are made to develop and raise funding. Existing financial institutions are not willing or capable of servicing the needs of infant businesses and there is little reason to believe that patchwork changes in their charters would remedy this situation. Further, there is little, if any, public awareness of the availability and desirability of SWECS products. Further, it is reasonable to hypothesize that the public credibility of some of these. new technologies is minimal.

This report reviews in some depth the underlying conditions for the situation described above. This review analyzes current policy efforts and existing institutions that handle financial transactions. Although the U.S. economy is as strong and resilient as any in the world, it is not truly geared to handle supportive type programs. The implied dichotomy of a free enterprise vs: a planned economy almost guarantees difficulties in the process of creation and implementation of mechanisms to support new industries. Yet, since alternative energy fits high national energy policy it is imperative that these vehicles be established.

The recommendations reflect this underlying data, and are broken into two distinct categories:

Specific Manufacturer Oriented--meaning those actions that will aid present SWECS manufacturers to cope with the existing conditions of the financial marketplace and help him to maximize his chances to secure the funds necessary to continue to exist and grow and hopefully reach the stage 
where the marketplace can define his business as a success. At that point, when the business is legitimized in the marketplace the marketplace's sources of funding become more available:"

Policy Oriented--relating those marketplace factors that exist as a : consequence of federal and state legislative and regulatory policy. These issues must be dealt with in turn at these levels and via mechanisms designed to operate in that environment.

There are two basic issues facing current manufacturers of SWECS. One is money and the other is market and both are tied-up inextricably in the aforementioned matter of raised expectations. The federal government desires the speed-up of the commercialization process for a technology that is generally unfamiliar to the public. This creates a conceptual block in the commercialization process which is manifested by a lack of demand for the product. With no demand there is no incentive for the financial community to operate in a normal fashion. As a result, raised expectations go unmet. In order to break this cycle, forces outside the marketplace, specifically direct federal financial aid, must be provided to get the SWECS industry into the marketplace where the existing forces can operate and indeed meet the expectations raised by government.

This report details the variety of specific financial institutions that do and will play a role in the development of the SWECS industry. In addition, less direct but equally important issues are analyzed that affect the ability of SWECS manufacturers to develop. These are:

- Inflation

- Tax policy

o Regulation

- Federal R\&D and procurement policies

The recommendations as mentioned, cover two categories--specific manufacturers and policy. The recommendations included in this report are:

Specific Manufacturer Oriented

o Further develop clearinghouse of SWECS product information

o Develup confidential arid authorized SWECS business consulting service

o. Video information package on how to secure financing

- Develop a theoretical optimal distribution channel for SWECS technology. 


\section{Policy Oriented}

- Permit tax deferred reserve for market makers in the securities business

- Further reduction of capital gains tax on investment in the under five million dollar equity market

- Roll-over provision for capital gains involving new and small business

o Amend the employee stock option requirements

o Permit three year accelerated depreciation for machinery and equipment

o Permit public investment in professionally managed venture capital firms

- Limit the liability for attorneys and accountants involved in securities issues

- Analyze the viability of funding SWECS manufacturing through the utilization of institutional structures similar to State Development Corporations (SDC) and Local Development Corporations (LDC).

The timeliness of examining the issues covered in this report can be seen in the economy today. With prime interest rates running at fifteen percent and above, the plight of SWECS manufacturers is intensified. Fifteen percent prime rate means eighteen percent and above money for speculative businesses such as SWECS manufacturing. At such costs there is no capital for them and even if they could afford it, the fact that such rates exceed many state usury levels also curtails availability. Without the immediate actions outlined in this paper, few, if any, SWECS manufacturers that are small businesses will survive many months into the future. 
TABLE OF CONTENTS

Introduction

Background - The Context of

The Marketplace

The Financial Resource:

Institutions and Techniques' 10

Commercial Banking 11

Venture Capital 14

Investment Bankers $\quad 16$

Small Business Administration

Small Business Investment Companies 24

State Development Corporations and Local Development Corporations 26

Life Insurance Companies -Limited Applicability for SWECS Manufacturers Today

Savings and Loan Institutions $\quad 30$

Financial Issues . 34

Recommendations. 48

Attachment A 


\section{INTRODUCTION}

This paper is intended to provide the reader with a background of the extent to which macroeconomic and microeconomic factors affect the ability of small wind energy conversion systems (SWECS) manufacturers to finance their corporate existence and growth. This background should, in turn, enable.. SWECS manufacturers and government officials to ascertain the means ito make private financing more accessible.

In order to bring SWECS manufacturing to a point of being commercially viable, manufacturers must progress through a variety of corporate and product development stages, each containing its own financing problems. In order to discuss the financial problems facing SWECS manufacturers this paper initially provides a background that examines several marketplace considerations that focus the financing problems facing SWECS manufacturing.

This report then continues by detailing the variety of institutions. and financing techniques within the financial community in order to demonstrate the diversity necessary to fulfill the differing financial needs that SWECS manufacturers have at each step of corporate/product development.

Based on the way the marketplace considers the venture of the emerging SWECS industry and the characteristics of the institutional providers of financing resources for SWECS manufacturers, this report then proceeds to focus on the financial problems facing SWECS manufacturers. These problems, affecting the marketplace and the manufacturer directly, were identified as a result of extensive research through written source material (see. Attachment $A$ at the end of report) as well as through conversations with SWECS manufacturers, lenders, investors and governmental officials. This portion of the paper includes a matrix outlining a variety of developmental considerations in the context of life cycle stages of corporate growth.

Finally, this report recommends several actions, some aimed at helping the SWECS manufacturer directly and some aimed at stimulating the marketplace so that it may in turn be more responsive to SWECS manufacturing.

It is essential not only to describe the financial problems facing SWECS manufacturers, but to understand the context in which the SWECS manufacturers operate and in which their financial problems arise. The problems are not all simple, nor straightforward. There are extenuating circumstances beyond the manufacturers' own control. The sense of urgency in the nation's energy policy pushes for the commercialization of technologies at a rate faster than would naturally occur. At the same time, the commercialization potential for SWECS is influenced by the financial realities that have helped shape the current economic marketplace. What this report does is to present such realities and to point to areas that SWECS manufacturers can address within those external realities. 


\section{BACKGROUND - THE CONTEXT OF THE MARKETPLACE}

The federal government has stated that it is in the National Interest to lessen the nation's dependence on imported foreign oil. As part of this effort, the present administration has supported the development and use of al ternate energy technologies. The effort to achieve the above two goals has resulted in the realization that a multitude of problems and barriers stand in the way. All too of ten the policy response to this realization has been to offer as an answer a multitude of proposed solutions and palliatives, each aimed at some specifically identifiable and discrete problem. As each problem and its proposed solutions become institutionalized it becomes increasingly difficult to see larger relationships between events, institutions and policies. While this study does not pretend to describe, analyze and solve the total probiems associated with energy, it does acknowledge that the problems it seeks to resolve concerning the financial issues facing the manufacturers of small wind energy conversion systems (SWECS) exist as part of larger contexts. This acknowledgement addresses more than a mere definition of problems by focussing on underlying causes and relationships. Thus, it is possible to realistically deal with the issues that control the more immediate financial problems facing SWECS manufacturers.

Before examining the specifics of financing SWECS manufacturing, it is important to mention several issues that are vital to understanding the problems SWECS manufacturers face. The first issue involves understanding that SWECS manufacturing is part of the grouping identified as new technical enterprises. The second issue is an expansion of the first and involves understanding SWECS manufacturing as part of the small business sector of the nation's economy. The third issue is chronological and involves understanding the desire to stimulate the manufacture of SWECS technology within the time frame that energy has emerged as a recent issue. This includes understanding what was happening with the institutions and policies that directly affect the ability of SWECS manufacturers to develop and produce their products.

The definition of SWECS as a new technical enterprișe (NTE) is not an idle definition. The emerging SWECS industry has all of the dilemmas of new industries and new businesses, plus the problems of small business. A lot of attention has been focussed in the last two years on small business, with its underlying problems of inadequate capitalization and lack of sufficient managerial resources. The national role of small business in employment (fifty-five percent), output (forty-eight percent), and innovation (fifty percent plus of new inventions) is unquestionable. Over ten million small businesses account for ninety-six percent of all businesses, and yet, as this report highlights over and over, this sector continues to be squeezed by a series of mostly uncontrollable forces that tend to refiect broad economic conditions as opposed to the special requirements for success of these companies. What is worse is that the current emphas is on small businesses totally ignores a critical distinction between small businesses and infant businesses. By definition small business has already developed 
a cash flow and has a managerial structure that permits it to use established financial channels." Infant business, on the other hand, relies exclusively on the "selling of the future" with all its hopes and uncertainties, and operates almost exclusively under negative cash flow conditions. Entrepreneurs of this type tend to be conceptually oriented as opposed to sales oriented, as their balance sheets clearly show. Besides the business risks posed by the managerial inexperience of most of these entrepreneurs, there are significant legal weaknesses that could potentially affect the future of the business. Access to capital requires a legal sophistication that is not found in this group. Existing requirements for adequate disclosure of risk when attempting to raise money place a major burden on the entrepreneur--a burden that he is not even remotely aware of. Improper actions put both the business and the entrepreneur on tricky legal ground with potentially devastating consequences for himself and his business:...

To date, the creation and production of alternate energy technologies, including SWECS, has been carried out in large measure (but not exclusively) by small businesses. This is not an unusual circumstance as the development of alternate energy technologies embodies innovative technological development, which has long been a strength of small business. In addition, the market, or demand sector, for alternate energy technologies has not generally been large enough to encourage large corporations to invest in. the production of the requisite technology.

Understanding the importance of new technical enterprises to the U.S. economy is critical as technology plays a vital role in growth employment and even return to the government in terms of tax revenues. The following analys is of the business community illustrates the role smal1. technology firms play in the overall economy.* The analysis identified three segments of the business community: young high technolcgy companies (Data General, National Semiconductor, Compugraphic, Digital Equipment, Marion Labs); innovative companies whose growth has been dependent on the continuing introduction of technological products (Polaroid, 3M, IBM, Xerox, Texas Instruments); and mature companies whose products have not been as subject to technological change (Bethlehem Steel, DuPont; General Electric; General Foods, International Paper, Proctor and Gamble). A variety of comparative categories were developed including: cumulative annual sales, new jobs and compounded annual growth in terms of income taxes. The analys is covered the five year period of 1969 through 1974. The following figures summarize the findings of the study:

\footnotetext{
*Based on "The Role of New Technical Entreprise in the United States Economy." M.I.T. Development Foundation, January, 1976.
} 


\section{Young High Tech Innovative Mature}

Cumulative

Annual Sales

(\% Increase

and ending

$\$$ figure)

New Jobs

(Increase

in \# and \%)

$42.5 \%$
(\$857 million)

Compounded

Annual Grnwt.h

in Income Tax

Provision

(\% increase and

ending $\$$ figure)
34,000

(five fold)

$13.5 \%$

(\$22 billion)

107,000

$(24 \%)$

$34.1 \%$

(\$57 million)
$8.5 \%$

(\$2.3 billion)
$11.4 \%$

(\$37 billion)

26,000

$7.8 \%$

(\$1.5 billiọn)

The above figures clearly show that the young technology companies are vital to the growth of the economy as well as to the continuation of innovation. In absolute terms, the young technology companies added more jobs than the mature companies even though their ending sales were less than three percent of the mature companies. Likewise, the innovative companies added four times as many jobs as the mature companies, with sales only fifty-eight percent of the latter's figure. These figures suggest that investment in mature companies is targeted toward the automation of production, as an effort to increase productivity and maintain a competitive position. A consequence of such a strategy is often not to increase employment. In fact, in an effort to cut costs in order to increase productivity, the mature company may seek to reduce employment. The tabular break-out on the following page provides more detail on the figures summarized above. These more detailed figures also provide a comparative base of twenty years for the innovative and mature companies. This twenty-year scope is provided to show that the statistical comparisons were not unique to the coriditions of the 1969-1974 period.

A second analysis surveyed approximately three hundred twenty-five technically-based companies and selected seventy-seven younger companies formed in the 1971-1975 period.* Among other things this survey showed the overall return to the economy for equity capital invested in the companies surveycd. For cach one hundred dollars of equity capital invested in the companies, the following results were realized in 1976 alone:

*Western Electronics Manufacturers Association Study. 
Sales \& Employment Data 1945-1974 \& 1969-1974

\section{Sales Data}

Sales
1974

Sales
1969
(\$ in millions)

Sales
1945

Ann

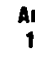

Annual Rate $969-1974$

4

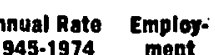
45-1974 ment

$\%$

$\begin{array}{lr}= & 140.5 \\ = & 54.3 \\ = & 50.2 \\ = & 36.8 \\ & 24.5\end{array}$

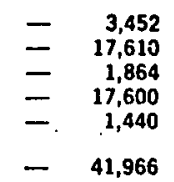

170
1,710
637
4,615
465
7,597

Total

Innovative Companies

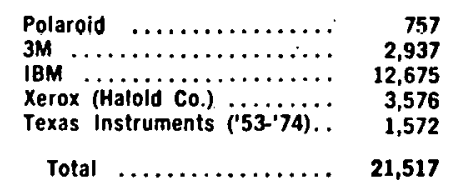

522
1,613
7,197
1,483
832
11,647

16.8
63.6
141.7
6.7
27.5

7.7
12.7
12.0
19.2
13.6
13.2

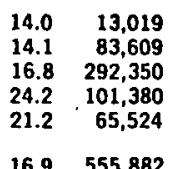

N.A.

13.2

$16.9 \quad 555,882$

Mature Companies

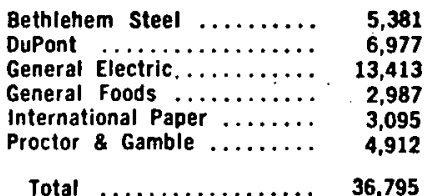

2,928
3,655
8,448
1,894
1,777
2,708
21,410

$\begin{array}{rr}1,327 . & 12.9 \\ 631.6 & 13.8 \\ 1,298 . & 9.7 \\ 307.1 & 9.5 \\ 240.0 & 11.7 \\ 342.5 & 12.6 \\ 4146 . & \end{array}$

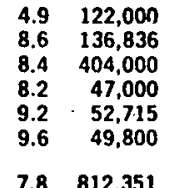

4,146 .

11.4

$\begin{array}{ll}7.8 & 812,351\end{array}$

\section{Employment Data}

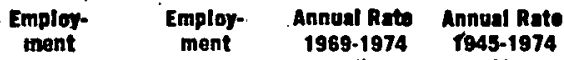

1869

1945

\%"

\%

Source: Moody's Industrial Manuals, Moody's Investor Services, Inc., New York, New York 
Export sales

$\$ 70,00$

R\&D expenditure

33,00

Federal corporate income taxes paid $\quad 15.00$

State and local taxes paid

Personal and federal income taxes

paid through withholding

5,00

15.00

Aside from any indirect benefits, the federal government received a direct benefit of thirty dollars of tax revenue in 1976 for every one hundred dollars invested in the period 1971-1975 in the companies selected. In order to put the federal.government's gain from investment in perspective, it must be understood that a thirty percent annual rate of return would delight any venture capitalist.

The fact that small businesses (in most cases, infant businesses) make up the majority of the alternate energy production capacity today says a . great deal about the nature of the problems facing the manufacturers of these technologies, including SWECS. Obtaining financing has always been a problem for small businesses but economic and regulatory conditions have arisen in the past ten years that have had a profound impact on the ability of all small businesses to form capital. While the conditions that have developed over the last decade will be discussed in more detail later in this report, it is clear that the problems facing SWECS manufacturers are a combination of issues involving capital supply, government regulation, tax policy, and federal procurement and contract procedures. The impact of these issues becomes clear when capital availability for the recent past is examined.

The number of initial public offerings has dropped dramatically over the last ten years. In 1969, five hundred forty-eight companies with net worths of under five million dollars raised almust une and one-half billion dollars. In 1975, unly rour companies ralsed about sixtcen mill iun düllars. In 1977, twenty-one companies raised eighty-two and one-half million dollars. By the fall of 1978, there had only been nine initial public offerings.*

Many investment houses that started out to help small businesses are finding that the average size of offerings has increased. The costs of going public are a major reason for this. Since the 1960's, the fixed costs of registering with the SEC have increased from an average of between fifty thousand and seventy-five thousand dollars to two hundred and two hundred and fifty thousand dollars. In 1977, nineteen initial public offerings were completed. The average cost was two hundred eighteen thousand, six hundred dollars, not including underwriters' marketing costs.

*Testimony of william Hambrecht before the U.S. Senate Select Committee on Smal1 Business, September 21, 1978. 
With such events, small businesses have had a hard time going public. . As William Hambrecht said:

If (the companies) are under $\$ 15$ million in revenue and $\$ 1$ million in net-after-tax profit, it is usually hesitant to risk $\$ 150,000$ - $\$ 200,000$ to prepare an S-1 Registration, particularly as they have no guarantee that the offering will be successful.

To raise two million dollars may cost three hundred sixty thousand dollars including underwriters' spread. Faced with such figures, few offerings under five million dollars are coming to the market.

A variety of actions contributed to capital constriction in the last decade for small businesses. These include a sharp change in tax policy beginning in 1969, that decreased incentives for savings and stimulated consumption and the utilization of debt financing instruments. The tax on capital gains increased sixty percent, spiraling upward toward the tax on ordinary income. This trend has been reversed somewhat by recent tax legislation. Tax legislation and inflation contributed to a withdrawal from the equity marketplace by the individual investor in the magnitude of twentyfive billion dollars for the period 1973-1978. The subsequent rising importance of the institutional investor had some negative consequences for entrepreneurs in new technical enterprises. Under the 1974 Employee Retirement Income Security Act (ERISA) portfolio managers of pension funds were reluctant to invest in potentially risky investment because of guideline provisions that held managers personally liable for imprudent investing. The result was simply a withholding of a very large pool of capital liquidity from start-up and small business ventures. Recent changes in the interpretation of the ERISA guidelines, like recent changes in the tax system, are opening up new opportunities for financing. However, these recent changes were not in place at the time that the energy situation underwent an abrupt change. One final occurrence merits mention in regard to the issue of capital availability and timing over the past decade. The consequences to tax policy, rising costs involved with going public, ERISA legislation and inflation were compounded by a definite consolidation within the investment banking community. Smaller brokerage houses faced with the economic problems were merged, consolidated, or liquidated, Consequently, there have been fewer. small broker/dealers to handle smaller issues. Entrepreneurs have been faced' with either finding no underwriter or paying the higher fees associated with larger overheads in the bigger investment banking houses.

Several recent changes in areas directly affecting capital formation should be mentioned at this point. While it is important to note these changes, it is too early to see what their impact will be. Changes in the capital gains tax provisions and clarification of the ERISA guidelines have a]ready been mentioned. In addition, some recent successes by companies that obtained venture capital have stimulated the market, as well as. has an increase in corporate acquisitions. In the last year, entrepreneurs 
raised seven hundred fifty million dollars which is about the same amount raised in the whole 1969-1977 period, But, it is also important to note that the way providers of venture capital are doing business has changed. They are far more conservative than they were in the "go-go" period of the mid- to late 1960 's. Risk minimization is important. While more capital is available, it appears that most of it is going to firms with established products that are looking for expansion capital rather than to companies looking for start-up capital.

Once the various political and economic issues affecting the various alternate energy technologies are identified, it becomes clearer that the problems concerning the commercialization of small wind energy conversion systems rest more with the marketplace than the technology. The technology is well-developed and the financial needs have to do with getting the technology and its manufacturers from the post-research and development stage to the stages of early company growth. At the same time, the SWECS manufacturers do not have mature distribution systems that established companies have. Policy-makers must devote their attention to where manufacturers of the technology are today rather than to where they have been or some day might be. The position that many manufacturers are now in can be graphically described as a "survival gap", which must be negotiated until the level of sales is sufficient to offset operating costs. Essentially, success in the marketplace results from uninterrupted sequential forward movement from concept to research and development (R\&D) and on to marketing. Early analysis indicates that a readily identifiable gap between R\&D and marketing exists in the product line development of new al ternate energy technologies. This "Survival Gap" is an area where fast movenient is required if the manufacturers are to survive. As a result, existing government assistance programs do not always lend themselves as sources for financing. The speculative nature surrounding the emergence of these alternate energy. technologies disinterests most established financial institutions. These conditions, when coupled with the virtual disappearance of venture capital, creates hardships for start-up companies, especially in these areas of great technological and marketing unknowns.

The irony about the federal government's desire to spur the development and production of alternate energy technologies is that it has stimulated activity in an economic sector that has experienced serious problems, many as a result of the federal government's own policies and reactions. It is essential to determine whether conditions affecting proposed solutions to the nation's energy problems are such as to aid in so?ving the problems or whether existing conditions will actually impede progress by transferring additional complications to an already serious problem. It is time for policy-makers to examine conditions of the marketplace and not just conditions of the technology if today's irony is not to become tomorrow's travesty.

- Specifically, the new energy technologies represent very new markets and by definition a new market is not large enough to attract big business. If market size is coupled with high risk you get an almost total exclusion of large companies. High risk plus small market size almost universally 
means operating under negative cash flow conditions, which in lay terms simply means that the entrepreneurs attempting to develop their businesses will find some tough times ahead--regardless of the quality of their ideas. Because alternative energy technologies fit within a high policy/goal objective of the federal government, a variety of programs are set in motion to "help the industry." These government programs tend to increase the size of the market and, thus, lower the risk with the unintended by-product of squeezing out the small pioneering entrepreneur.

A few of the participants in this field strongly believe that this industry will not succeed until large companies take over most of the development. It is believed by some that institutional bias will virtually rule out significant in-roads by the current participants into a power-grid oriented energy distribution and transmission. system. While this view is not prevalent, it is widely disseminated. 


\section{THE FINANCIAL RESOURCE: INSTITUTIONS AND TECHNIQUES}

The following section is included in order to give a straightforward description of the various financial resources that are a part of developing a commercialized SWECS industry. The variety of financial resources that are available for use at each stage of corporate/product development are presented in the context of the various institutions that offer the specific resources or techniques. The techniques by themselves are inert but the institutions activate them through use and, in doing so, bring into play the various philosophies, operating principles and informational needs of each institution.

The focus of this section is on how these institutions normally operate, not how they "should" operate in order to optimize the potential for commercializing SWECS technology. These institutions are part of the economic marketplace and are organized to interact with other established marketplace organizations. The beginning of this report states that the SWECS industry has not yet developed to the point of being part of the economic marketplace mainstream. This section illustrates that fact. The description of financial institutions and resources also graphically points out. how much of the SWECS industry does not yet fall into the criteria that makes up the financial institutions customer base.

This report describes the stages of development of SWECS manufacturing in order to understand the financial issues that affect each stage. Most of the stages lie in front of SWECS manufacturers, and correspondingly, the financial institutions that affect each stage are part. of the future more than the present of SWECS manufacturing.

The current response of financial institutions to the SWECS industry indicates that the industry is not yet part of the economic marketplace. Given time, the SWECS industry may naturally become part of the marketplace. However, the natural evolutionary process does not coincide with the government's time frame for bringing the technology to a commercialized state. If the process is to be accelerated, governmental action must be aimed at getting the SWECS industry into the marketplace, as defined by marketplace participants, as quickly as possible.

The current lack of initiative that the financial community has shown toward financing SWECS technology indicates that the industry is not yet part of the economic marketplace. Given time, the SWECS industry may naturally become part of the marketplace. However, the federal government's desire to bring SWECS technology to a commercialized state creates a time frame that is too short for this to occur. If the process is to be accelerated, governmental action must be aimed at getting the SWECS industry into the marketplace, as defined by marketplace participants, as quickly as possible. 


\section{Commercial Banking}

The commercial banker is a key element in the financial development of a new enterprise as a provider of temporary rather than permanent financing. He is usually the first financial adviser that an entrepreneur has and based on his knowledge and the creditworthiness of the borrower, the banker will offer advice, counsel and short-term funds. Based on the bank's own lending parameters and an assessment of the viability of the enterprise the lender may help as much as possible.

- Why Banks Lend Money

In order to utilize the resources available through commercial lenders, borrowers must understand what the commercial banks' own objectives are. Commercial banks are in the business of "renting" money. Each day a wide variety of opportunities arise for the banker to lend funds to businesses of various sizes, to individuals and to government. The loans include varieties of commercial, consumer and real estate needs. Behind all the analysis bankers do in examining a potential loan rest two questions: how much does the bank stand to gain from the transaction and what is the extent of the bank's risk? Maturities, costs, and yields vary widely from one type of loan to another, and the mix must be taken into account by the bank in structuring their own portfolios. The commercial bank as a business is interested in its own growth, liquidity and earnings in order to attract deposits and capital. Potential-borrowers must be aware that they are competing with a large number of other potential borrowers and that the particularities of any borrower's situation will be seen in the context of the bank's overall policy as well as on the merits of a particular loan.

\section{- Lending, Short-Term/Long-Term}

The financial resources made available through commercial bankers are generally categorized as debt capital or borrowing. Unlike equity capital, which is raised by selling a part of one's business, debt capital requires repayment to the lender. Lending to commercial customers falls into shortor long-term loans. Short-term loans generally do not exceed six months but may be extended fo'-purposes such as financing accounts receivable or building inventories for a seasonal demand. The repayment of such loans is predicated on liquidating curren'assets, be it payment of outstanding accounts or proceeds from the sale of stockpiled inventories. Short-term loans may be unsecured or secured by some corporate asset.

Long-term lending differs from short-term lending in terms of purpose of the loan, amount of the loan, time to repay the loan and sources for repayment of the loan. Unlike a short-term loan which is repaid by liquidating a current asset, long-term lending is repaid from corporate earnings over a period of time. In short, production is usually the purpose for long-term lending as well as the source for repayment. 
Loan Backing, Creditworthiness and Collateral

The early stages of the commercial banker/borrower relationship is characterized as a personal rather than a corporate banking relationship. While both the banker and entrepreneur are hoping for major corporate growth, the entrepreneur for his own gain and the banker for a major banking relationship including sizeable deposits; the immediate basis for lending is the creditworthiness that the entrepreneur possesses.

The problem of borrowing, especially in the early developmental stages, is that of loan security or collateral. If the potential borrower is aware of usable collateral or methods of securing a loan, he can open financing techniques that might not otherwise be available.

One way of strengthening credit is to add the creditworthiness of other individuais by having an obligation cosigned, guaranteed or endorsed. Each of these techniques differs in terms of the liability of the "bolstering" party. A cosigner or comaker is directly liable in the same way as the signer or maker. A guarantor is a secondary signer who guarantees payment, such as the officer of a company guaranteeing payment by the company: An endorser carries only a contingent liability. The endorser is expected to pay if the maker fails to meet his obligation.

Loans based on accounts receivable have already been mentioned. The bank may ask for direct payment by the purchaser of the goods or simply by the borrower, upon receipt of payment through his customer.

Various assets can be assigned to the lender including savings accounts and life insurance policies. Stocks and bonds may be used as collateral but the value of the collateral will depend on the market value of the stock or bond at any given time. Should the value fall too far, the borrower may be required to provide additional security.

- Corporate Growth and the Limitations of

Commercial Bank Short-Term Lending

If the entrepreneur continues to grow and develop, he will continue to utilize his commercial banking contact for short-term credit. For a period of time short-term credit satisfies both borrower and lender. However, an ironic situation begins to occur as a business enjoys continued growth. As growth continues so do the requirements for financing that growth. At this stage of corporate development debt uscd to finance growth cscolotes faster than the retained earnings of the company. As a result, while sales and growth create an outwardly successful image, the ever increasing debtto-equity ratio adversely affects the company's financial statement. The continuation of the banking relationship based on short-term borrowings may present problems from the banker's perspective as well as during a period of rapid company growth as the amounts required by the borrower may begin to "bump-up" against the bank's lending limits. 
The circumstances indicated above do not mean that a company grows beyond the facilities of a commercial bank. Instead, it illustrates the fact that the commercial banks are a temporary financing resource, suited to fill short-term or intermediate-term financing needs., rather than a source of permanent capital. As a company progresses through the stages of its corporate development, the commercial bank is a financial resource that is used almost continualiy for a variety of purposes.

\section{- Summary}

How all of the above facts relate to the SWECS manufacturer may have a special significance as the commercial bank may be the financial resource of first resort. However, if the SWECS entrepreneur is unable to secure. initial short-term financing from a commercial bank, his chances for proceeding to further development stages where other sources of financing are available are almost negligible. In such circumstances, the entrepreneur can expect that the banker will be:

o Attentive but cautious.

o Interested in what you plan to do with your idea and how you plan to proceed, not just in the idea itself.

- Interested in minimizing the risk side by asking for collateral or a strengthening of the credit.

- Talking initially about short-term money if there is interest in financing at all. should:

- In order to maximize the chances to secure funds, the entrepreneur

: o Not expect the lender to automatically cooperate just because the business is timely, saves energy, or is in the "national interest."

- Be as prepared as possible to discuss business plans based on activity to date and the proposed steps to become commercially viable.

- Be prepared to suggest potential collateral.

0: Be prepared to explain how much money is needed and exactly how the funds will be spent.

- Know how the borrowed funds will be paid back.

The entrepreneur can save a great deal of time by anticipating as much of what the lender will ask as possible. At the early stages of corporate/ product development time means money to the entrepreneur and money means survival. 
Venture Capital.

The inability to continue financing growth through debt issues without increasing the equity. base places the entrepreneur at one of the crucial financial positioning points in the development of a corporate enterprise. Management realizes that the ability. to increase the company's equity base from internal resources does not exist and they have become aware of the needs for longer term financing.

Companies unable to provide necessary financing internally usually pursue one of two different routes at this point of their development. One alternative is to turn to the government for help, which basically means turning to the Small Business Administration (SBA). The other alternative is to continue seeking financial assistance in the private marketplace. With an equity base that has limited the ability to secure debt financing, a company must seek equity funding in order to continue its.growth. Equity funding for companies at this stage of growth is one of the financing areas in which venture capital companies are involved.

\section{- Characteristics of Recipients of Initial Venture Capital}

Companies that are in a position to be recipients of venture capital at this stage have gone beyond an initial or start-up stage; that stage where financing is provided by private individuals, be they owners of the company or friends or relatives of the owners: This stage of venture capitalists involvement is a transitional stage between personal investment and public financing. The company at this stage usually is on the verge or has already brought a product into production. Also, a commercial interest has usually been developed by this stage and the company has normally established a line of credit with a commercial bank by this point. The term "first stage financing" is often used to describe this phase. The . term "first stage" relates to the first of a series of venture capital financed stages that occur in the transition phase between personal financing and public financing, not to the first stage of a company's total financing history.

\section{- Second Stage Venture Capital Financing}

Venture capitalists also provide "second stage financing." The company.'s need at this point is usually for working capital and capital to finance expansion. Companies at this juncture are producing and shipping products and are experiencing increased marketing costs and an expansion of accounts. Despite rapid production expansion, the company may still be operating at a net loss. "Third stage financing" is similar to that of the previous stage with the possibility of acquisitions being a part of the company's plans. However., at this stage the company is usually breaking even or making a profit. 
- Bridge Financing

An additional stage of venture capital financing occurs shortly before a corporation is ready to "go public," or sell stock to the public in order to secure external financing. The stage, called "bridge financing, "usually occurs within a year of a company. "going public." The basis for repayment of the "bridge financing" is the proceeds expected from the public underwriting.

- Venture Capital and SWECS Manufacturers

Venture Capital provides a vital link between the initial short-term debt financing of commercial banks and the long-term equity financing provided by a public stock offering. This pivotal role is discussed in more detail in the following section, Financial Issues. For SWECS manufacturers who have successfully secured short-term financing from commercial banks and are faced with the need to move beyond that type of financing; it is important to understand the purposes and processes of venture capital. 
Investment Bankers

\section{- Investment Banking Services}

The investment banking resource has undergone some major changes in :" the last ten years. The mix of services varies from institution to insti-i tution; but, basically, the facilities offered fall into three areas: raising capital, counseling, and other services in support of corporate operations, or of investors.

\section{- Raising Capital}

The raising of capital falls into several areas including underwriting, private placements, syndication and the selling of commercial paper. Underwriting simply means that investment bankers agree to acquire and distribute a company's securities. By doing this, investment bankers free a company. : from the risk, time, and expense of seeking investors on their own. In. addition, the company has the necessary capital it sought. While the company has achieved its objective, the investment banker still has to distribute the securities at an established price. However, if the issue is "firm" (committed) the investment banker can lose a substantial sum if circumstances arise that force him to sell at a loss or even a break-even point. As a result, the pricing of an issue becomes a very important exercise for both the company and the investment banker. As the middle-man between issuer (the company) and investor (individuals and institutions), the investment banker seeks to establish a price that satisfies both. The process of establishing the "right price" starts with preliminary meetings to discuss financing requirements such as price, timing of the issue, and the form of the issue. These preliminary discussions serve an additional purpose, which is to see if any major differences exist as to financing philosophies or approaches.

If the preliminary phase indicates that the relationship between issuer and investment banker is to continue, then there follows a detailed research into the company's background and operations. This investigation includes financial audits, legal reviews, and any necessary technical studies or examinations. The information gathered at this point provides a basis for information to be contained in the issues prospectus to be provided to potential buyers of stock. The culmination of this phase is the signing of an underwriting agreement with the company. Even at this stage the price that the underwriter will pay for the issue is not agreed upon. Price determination is normally made just before the offering is made available to the public.

\section{Pricing of Stock}

Pricing mechanisms vary with the situation. In a case where the company already has shares outstanding, the pricing mechanism may be quoted as a discount figure from the quoted price of the outstanding shares. Investment bankers sometimes provide an out for themselves in case the quote on the outstanding shares drops dramatically prior to the offering date. 
In cases of privately held companies; the determination of price can become very difficult as the question becomes one of assessing the price where investors will be attracted to the offer. Usually, characteristics of similar issues are used as a basis for comparison. If such comparisons do not exist or if the investment banker feels a stronger comparative basis is needed, then criteria such as consistency of earnings and growth rates are used. In cases where no track record exists, especially in start-up situations, a completely different approach must be used. "Value/potential" becomes a critical criteria. Most importantly, "value/potential" assesses people and management capabilities. The essential step of transforming an idea into a business requires quality people, a sound plan and an understanding of the realities of cash flow management. As a result, the ability to successfully invest in such ventures requires knowing how to analyze those resources.

\section{Registration Statements}

The investment banker plays a vital role in the underwriting process in helping to prepare registration statements for the Securities and Exchange Commission, if such registrations are required. These statements must contain detailed background on the issuer and an accounting of how the issuer intends to use the proceeds from the proposed offering. This process necessitates legal work by an attorney. Investment bankers are in the position of providing the assistance of lawyers who are specialists in SEC work. The preparation of the required statements is not something that can easily or adequately be handled by an attorney without backgrourid and experience in the field.

\section{Syndication for Selling Stock}

Increasingly, investment bankers who carry on all of the background investigation do not handle the total underwriting on their own. In an effort to minimize their risk and to provide a more extensive marketing network, they will ask other investment bankers to participate in purchasing and distributing an issue. These investment bankers form a syndicate or selling group that operates only for a particular issue which buys portions of an issue at wholesale and retails those same portions.

Syndications can be structured in various ways, but the main determination is whether the liability is divided or undivided in terms of any unsold amount of shares. Under a divided agreement an underwriter is responsible for selling only a predetermined number of shares. Under an undivided agreement, an underwriter would be responsible for selling unsold shares even if its predetermined quota was met.

\section{Compensating the Investment Banker}

Compensation for investment bankers who act as underwriters is based on the spread between the amount paid to an issuer and the amount obtained from selling the issue to investors. The spread is split in a predetermined fashion between originating underwriters and sellers of the securities. Spreads tend to be larger for small or new offerings because of greater risks. 
Investment bankers can be compensated for services, such as handling private placements or arranging acquisitions. The form of payment can be either a retainer and/or a fee.

\section{Private Placements}

Investment bankers can arrange private placements with individual or institutional investors. Normally, such issues are debt instruments but. can include equity securities as well. Private placements have the advantage of cutting the time and costs associated with the waiting periods and reporting regulations of public issues. However, costs can still rise if the investor demands incentives such as warrants for additional. stock.

\section{Commercial Paper}

Investment bankers can sell commercial papers, which are short-term corporate notes. Usually the only companies able to sell lheip paper are: large organizations with well-established credit. The sale of commercial paper is handled as a market and that market can be subject to abrupt changes. There are no fixed interest rates, only competitively determined discount rates. The discount rate includes a commission, usually one-eighth of one percent. The stimulus for activity in this market is that the rates are usually lower than the borrowing rates of banks and do not include compensating balance requirements.

\section{- Counseling}

Aside from underwriting, investment bankers provide counsel to company clients, especially in areas such as acquisitions and divestitures where the investment banker is continually exposed to the processes of such activities, unlike a company's own financial staff.

\section{- $\quad$ 0ther Services}

Other services that some investment bankers provide include project financing, leasing, money management, brokering, real estate and international financing. Government bonds, notes, bills, and municipal bonds are handled by some investment bankers as well.

\section{- Investment Banking and SWECS Manufacturing}

For the SWECS manufacturer it is important to understand the different. focus of various investment bankers. For the most part, SWECS manufacturers are not of a size or in need of the capital that would involve a large investment banking house. For such financial concerns their interest is in midsized companies and up, which have evidenced outstanding growth and have an cxciting story that brokcrs can use to sell customers. These are companies looking for ten million dollars or more!!

However, there are investment bankers who specialize in small start-up companies that have little or no track record. Such companies, when they 
do "go public" are in the OTC, or "over-the-counter"! market. . There are few, if any, objective benchmarks such as being "mid-sized" or evidencing outstanding growth. The market is highly speculative: and the investment bankers in these situations must rely on very subjective criteria, such as the people and the management techniques involved in the company's operation. There is one similarity to the criteria of the larger investment banking house, inamely, an exciting story. What the entrepreneur has to realize is that it is the investment banker, not the public, who must be excited by the company"is story and potential. If the investment banker is not "turned-on" there will il not be any money. If the investment banker is "turned-on" he will certaininy convey the excitment and potential of the company to the public as it iis from the public that the investment banker will recoup his investment.

The OTC type financing assistance generally starts with offerings of one and one-thaif million dollars, on up and utilizes a regulation $A$ or Form S-78 format. (Regulation $A$ and $S-18$ registrations allow for less disclosure and fewer audited financial statements than a full registration.) In some ways thiis form of financing is similar to that of a venture capitalist.

Currently, the majority of SWECS manufacturers cannot find financial assisistance from traditional investment banking sources, especially when theil ir needs and what is available is defined by a ten million dollar entry fee. Several SWECS manufacturers may be at the stage where an OTC type offering is feasibile. However, a great portion of the SWECS community may not even be at that stage of development yet.

Lilke most of the traditional financing resources, investment banking rellates more to the development stages ahead of SHECS manufacturers than to where the manufacturers are today.

- Summary

To summarize the activities of investment bankers, their services ïncliude:

- Raising capital.

(o) Counseling.

( ) Support services for corporate and investar clients.

These investment banking activities are carried on at different levels:

( $\quad$ Traditional Investment Banking Houses

- Interested in mid-sized companies

- Ten million dollar and above issues

- Outstanding growth record

- Objective analysis

- Exciting story. 
o OTC-type Investment Banking Houses

- Start-up situations

- Speculative

- Subjective analysis

- One and one-half million dollar and above issues

- Exciting story. 
Small Business Administration (SBA)

The purpose of the Small Business Administration is to enable businesses which do not meet the credit standards of commercial banks to secure funds. The SBA has three potential roles to play in providing business loans. Two of the roles, immediate participation and guaranteeing loans, are done in conjunction with financial institutions in the private sector. In every case the SBA seeks to maximize participation by commercial lending institutions. The SBA can provide up to a ninety percent guarantee on loans made by commercial lenders. If the commercial lender decides against the guarantee method, the customer can ask for an immediate participation loan which the commercial lender and the SBA share in jointly, on an agreed on basis. The SBA will consider direct loans only if the applicant cannot have his borrowing requirements satisfied solely by commercial lenders or by such lenders in conjunction with the SBA. The applicant should also be aware that funds for direct loans are scarce.

\section{- El igibility Requirements}

Eligibility for loans depends on being an independent business that is not dominent in its field. Also, the business must be unable to obtain financing at reasonable terms. Finally, the applicant must qualify as a small business under the following general size criteria established by the SBA. Annual receipts should not exceed:

- $\quad \$ 2-\$ 8$ million for service entities

- \$2-\$7.5 million for retail establishments

o \$9.5-\$22 million for wholesale

- $\$ 9.5$ million for general construction

- $\$ 5$ million for special trade construction

- $\$ 275,000$ for farming and related activilies.

In manufacturing, the size limits are defined as not to exceed two hundred fifty to one thousand five hundred employees. (Qualifying requirements, interest rates and payback periods are subject to SBA revision at anytime.)

\section{- Purpose of Loans}

The purpose of the loans covers a wide spectrum including: working capital, construction, expansion, equipment purchases, supplies, facilities, and machinery. SBA loan coverage may vary if there is a need to conserve funds. However, the maximum available to any one borrower is one-half million dollars for a direct SBA loan or for the SBA portion of an immediate participation with a private lending institution for loans made by a commercial bank and guaranteed in part by the SBA, the maximum is also one-half million dollars but considerations of exceptional circumstances may push the figure higher. 
- Interest Rates

Interest rates on the various SBA loans vary. Under the direct loan program the current interest rate is six and five-eighths percent per annum. This figure applies to the SBA's portion of an immediate participation, loan as well. Interest rates applying to the commercial bank's portion of an immediate participation are set by the private lender under a maximum ceiling set by the SBA. The same arrangement of the private lender setting rates under a maximum ceiling set by the SBA applies to loans under the guarantee program.

\section{- Löan Maturities}

Maximum maturities run to ten years, However, working capital loans are usually limited to six years. Parts of construction or real estate loans may have a maximum of twenty years.

\section{- Loan Collateral}

What the SBA requires in the form of collateral depends on the nature of the loan. The form of collateral may be real estale, a chatel mortgage, assignment of goods or contracts, in some instances current receivables, and personal guarantees or endorsements. The Smal1 Büsiness Énergy Loan Act of 1978 authorizes the SBA to make loans and loan guarantees to small businesses who manufacture, market, distribute, install or service any "generic" area of energy conservation. These loans, like others authorized by SBA, are aimed at small business development, not technological innovation. Applicants under the Small. Business. Energy Loan Act must meet and have the same qualifications as all other SBA loan applicants, which includes a four-to-one debt to equity ratio and a two-to-one current assets to current liabilities ratio. In addition, the maximum amount available for any single project under the 1978 Act is one-half million dollars which in many cases may not be enough to finance the development and commercialization of an emerging technological enterprise.

\section{- Summary}

Most SWECS manufacturers today do not have to worry about exceeding the size criteria for SBA loan assistance. The decision whether to seek SBA money, directly or indirectly, is up to each entrepreneur... However, the entrepreneur should expect:

- As stringent credit conditions as a commercial bank.

o Long processing time.

In sum; the entrepreneur must decide if he can and wishes to accept the liability required and if ${ }^{\prime}$ he can sustain the business during the time necessary to deal with the government red tape. In many cases the answer to one or both questions is no. 
The two major considerations that the SWECS manufacturer must assess when considering SBA assistance are:

- Length of time in considering and processing the loan application.

- The potential consequences of borrower liability for the entrepreneur.

The length of time that is given to considering an SBA application is an important issue for the SWECS manufacturer. Survival may depend on quick responsive action from a lender. Financial assistance that arrives too late is of no help to a business that has had to close its doors.

The issue of liability is al so of grave consequence to the entrepreneur. When an individual is asked to place his total personal financial worth on the line, he must think hard and realistically about the success/failure ratio. While asking an individual to place his financial being on the line insures a sense of commitment, it also retards the ability of an infant business to secure funds.

The structure of SBA programs is designed more for established smali businesses needing expansion capital than for new infant businesses needing seed or launch capital. The important point for the individual manufacturer to assess is the stage of his own company's development and whether the risks of SBA financing are affordable. Cases of successful SBA financing in the SWECS community show that in certain instances the SBA is an appropriate financing institution. However; not all manufacturers are in the same stage of corporate development and the SBA does not present affordable risks for al1. SWECS manufacturers. 
Small Business Investment Companies (SBIC)

The SBA was never intended as an institution that contributed to the long-term funding needs of growing and developing small firms. Instead, the charter of the SBA has been to assist small business concerns which have been unable to secure financing through commercial banks. The lack of an institutional entity to deal with the long-term debt and equity capital problems of the small business was finally addressed in the Small Business Investment Act of 1958. The program set up under the 1958 Act was designed to utilize and maximize existing private credit facilities and state and. local development credit facilities rather than to replace them:.

- Source of SBIC Funds

The SBA provides loans to small business investment companies (SBIC) or Section 301 (d) SBIC which are called minority enterprise small. business investment companies or MESBIC, with funds for financing cligible small. businesses for their growth, expansion, or modernization. In order to be eligible for such funds, the organization must be an SBIC or MESBIC organized for the sole act of assisting disadvantaqed entrepreneurs. The SBA requires a minimum capital of $\$ 500,000$, even though the statutory level is lower. An SBIC must prove that there is adequate capital for operating in an active and profitable manner. A MESBIC with limited capital must show that operating expenses can be covered without depleting its capital.

An SBIC can borrow three dollars from the SBA for every dollar of private borrowed capital, up to a maximum of thirty-five million dollars. If an SBIC has sixty-five percent or more of its total available funds invested in venture capital, it is el igible to borrow four dollars for every one of its private capital dollars, up to a maximum of thirty-five million dollars, provided it has capital of five hundred thousand or more dollars. The same conditions apply to MESBIC's except that the required venture capital investment is thirty percent and there is no limit on funding.

\section{- Interest Rates, Collateral and Loan Maturities}

Interest rates that SBIC must pay the SBA operate on the following basis. The SBA provides funds to an SBIC through its one hundred percent guarantee of the debentures sold to the Federal Financing Bank, which bear interest at comparable agency rates for paper of a similar maturity. Interest rates of MESBIC debentures sold to the SBA can not be less than a rate established by the Secretary of the Treasury, plus any other program costs the SBA may decide is consistent with its purpose. MESBIC's are eligible for a subsidized interest rate for the first five years in their debentures sold to the SBA, subject to repayment of that subsidy prior to distribution to any other stockholders. The maximum maturity of loans to SBIC's or MESBIC's is fifteen years. Security on the loans, provided as evicience of indebtedness, is a debenture of the SBIC or MESBIC licensee subordinated to any other debenture bonds, promissory notes, or other debts or obligations of the SBIC or MESBIC, unless the SBA in the exercise of reasonable investment prudence states otherwise. Adequately capitalized MESBIC licensees are eligible for SBA 
purchases of their three percent cumulative preferred stock in an amount equivalent to a portion of all their paid-in capital and paid-in surplus; the proceeds providing a part of authorized leverage,

\section{- Summary}

SBIC's have shown a tendency to supply: capital to companies that have been in existence for several years. This tendency illustrates a basic fact that the SBIC's and the SBA's small business definition excludes emerging or infant businesses. The fact that some SWECS manufacturers are in the emerging or infant stage means that SBIC's are probably not an appropriate or promising source of financing. Such a decision will depend on the development stage of the manufacturer and what the alternatives are. 
State Development Corporations (SDC) and Local Development Corporations (LDC)

State Development Corporations (SDC) provide an additional opportunity for the federal government, through the SBA, to participate in fostering new emerging enterprises without being the sole financial support. The SBA is authorized to match funds that are provided to SDC's by other sources. The stipulation for SDC's obtaining SBA funds' is that those funds must be used to provide equity capital or loans to small businesses.

- What Are SDC'S and How Do They Operate?

State development corporations are organized under a special act of the state legislature. The purpose of SDC is to promote and develop economic growth within the state by providing long term financing that is unavailable from other sources such as commercial banks or small business investment companies (SBIC). SDC's are private corporations operating on a for-profit basis. The funds that SDC's utilize are borrowed from traditional private financing sources such as commercial banks and insurance companies. Because of their charter they are able to borrow at low rates of interest. The borrowed funds provide a loan pool that is used to finance high risk situations that might not otherwise be funded. The interest paid by the high risk venture is substantially more than the interest paid by the SDC to the original financing source. However, the impact of the higher interest rate is offset by longer amortization periods that allow for the development of innovative ideas and products. SDC's may also carry federally guaranteed loans and they may buy equity in the borrowing companies.

Being a creation of the state government it is logical that placement of SDC funds depend on what will benefit the state as a whole. Such considerations do not always coincide with needs and interests of emerging companies with innovative ideas and products. However, if SBA funds are matched to other SDC funds, the focus is more narrowly defined, and certainly in keeping with the needs of the manufacturers of SWECS technologies.

The maximum amount that an SDC may borrow from the SBA can equal the total outstanding borrowings of all other financing sources. The total amount that the SBA has available for SDC loans is affected by annual budget allocations. Past experiences indicate that the average loan request from an SDC is between one-half million and one million dollars. The interest rate on SBA loans is published annually but the ceiling figure is eight percent. While the maximum maturity on the SBA loans to SDC's is twenty years, the normal practice is for the SDC to request five to ten year terms. Collateral or security for an SBA loan is on an equal basis with borrowed funds from other sources.

- What are LDC's and How Do They Operate?

A program similar to the one including SDC's, operates on the local level. The local development company (LDC) program operates through a corporation comprised of residents and businessmen. in a community. The 
purpose is to aid and improve a local economy. An LDC eligible for SBA loans must be an authorized local corporation formed for the promotion and development of local economic growth incorporated either as a profit or nonprofit under the laws of the state in which it expects to do business. At least seventy-five percent of the ownership of the corporation must be held by residents or business people in the community and there must be a minimum of twenty-five stockholders or members.

The purpose of SBA loans to LOC's include: 1and and/or building acquisition, new plant construction, machinery and equipment purchase, plant expansion or conversion. Such purposes may qualify, provided the project will aid a specific small business.

The maximum amount for an SBA loan to an LDC is one-half million dollars for each identifiable small business to be aided. The SBA participates on a cost-sharing basis. The LDC may raise funds by sale of stock or memberships, debentures, or provide cash equivalents such as land. The minimum amount that the LDC provides by such methods is generalily twenty percent of the cost of the project. The SBA will take a second lien position when local lending institutions participate in the SBA's first mortgage plan. The source of the loan funds may vary. The source may be a bank loan guaranteed by the SBA to seventy percent of the loan or one-half million dollars, whichever is less. In addition, the source may be a bank loan with an immediate SBA participation or a bank first mortgage loan and SBA direct second mortgage loan. A final source of funds may come directly from the SBA.

The interest rate on SBA loans to LDC's varies, depending on the source of the funds. For guaranteed loans the interest rate is defined as a legal and reasonable rate on the entire loan balance. For immediate participation the rate is defined as the legal and reasonable rate on the bank share and the published rate on the SBA share. For first mortgages it is the same combination of legal and reasonable rate for the bank share and the published rate for the SBA loan. Finally, the rate on direct SBA loans is according to the published figure. The maximum maturity for SBA loans to LDC's is twenty-five years plus the estimated time required to complete construction, conversion or expansion. The actual figure is fifteen to twenty years. Collateral on LDC loans from the SBA is a lien on the fixed assets acquired with loan proceeds. This then is taken as a way to assure repayment of the loan.

\section{- Potential of SDC and LDC Financing for SWECS Manufacturers}

In reality the ability of SDC's or LDC's to help SWECS manufacturers today does not appear great. The intent of these programs is to aid overall economic development, either at the state or local level. The manufacture of small wind energy conversion systems does not, today, necessarily meet that purpose. The major problems with SDC's or LDC's for SWECS manufacturers are:

- They do not specifically meet the needs of SDC's or LDC's.

- Funding delays due to government red tape. 
The concept embodied in SDC's and LDC's may, however, provide a good vehicle for funding SWECS and other alternate energy technologies.. The U.S. Department of Energy might well consider developing a plan for which the stimulation of alternate energy manufacturing rather than general economic upgrading is proposed. DOE could operate in the same manner that the SBA does for the SDC and LDC programs. Such a program would stimulate alternate energy manufacturing within the natural environment of the private sector rather than creating a direct subsidy relationship that virtually isolates the manufacturer from the surrounding business community and marketplace. 


\section{Life Insurance Companies -- Limited Applicability for SWECS Manufacturers Today}

Insurance companies as potential financing sources for SWECS manufacturers appear to be of limited value. As the chart on page 38 shows, insurance companies do not enter the financial picture until a company has reached a period of sustaining growth, with revenues of at least twentyfive million dollars. Insurance companies are basically providers of longterm financing. The criteria for such lending often does not apply to small businesses such as SWECS manufacturers. From the standpoint of the economics of insurance company investing, the cost of making loans to small businesses is usually considered high enough so that the insurance companies cannot charge a return on the loans that would make them as profitable as other lending opportunities, such as large business loans.

The one thing SWECS manufacturers can do if they are in a position: to discuss financing is to have available as much organized financial data, both past and present, as possible. In addition, the potential borrower should seek ways of reducing the cost and risk for the lender. The reduction of cost can be accomplished by clearly indicating the amount of longterm financing needed and how and when the repayments will be made. The lowering of risk can be aided by being prepared to offer collateral on the loan, such as real property or stock.

Clearly, insurance company financing is something that does not apply to most SWECS manufacturers today. 
Savings and Loan Institutions

- Financing the Buyer of SWECS Products

The financial resources available through savings and loan institutions (S\&L's) address most directly the consumers of smali wind energy rather than the manufacturers, particularly the consumers with residential applications of the technology in mind.

Mortgage lenders have a vested interest in residential energy costs in the sense that the increase in any borrower costs can at some point jeopardize the investment represented by a mortgage and the ability of the homeowner to keep up monthly mortgage payments. Energy costs have already had a significant impact. In some parts of the country, on a seasonal basis, monthly energy costs have excecded monthly mortgage payments. Such circum. stances raise questions not only about debt repayment but about initial credit evaluation as well.

The specific lending techniques utilized by any one S\&L depends on what that particular institution can do according to legislation, regulation and what it is used to doing according to tradition. S\&L's are either federally chartered, or state chartered. In the cases of the state-chartered. S\&L's the permissable lending activity can vary widely. Another major determinent of accessibility to funds from S\&L's is what particular lending techniques may be traditionally used in a specific part of: the country. A technique practiced widely in one part of the country may virtually be unheard of in another part.

The basis for utilizing the mortgage instrument is that the interest rate on mortgages tends to be less than that for alternative borrowing opportunities. The key in using the mortgage instrument is whether the original instrument has to be renegotiated in order to provide the necessary funds. Renegotiations involve increased costs which would have to be figured into the transaction. Increased costs can come about in another significant way. If a home buyer wishes to pay less than the traditional twenty percent down payment on a house, he is often required to provide personal mortgage insurance, thus incurring an additional cost. If a prospective homeowner is considering the addition of SWECS technology to a home he is considering buying, the additional cost of the technology, if added to the first mortgage may result in the buyer not being abie to put twenty percent down on the house. As a result he may be forced to purchase personal mortgage insurance, thus adding to the overall cost. The result may be a disincentive to purchase SWECS technology.

The following techniques cover a variety of borrowing opportunities available through an S\&L that best apply to the financing of SWECS technology:

Open-Ended Mortgages: Often a clause is included that allows borrowing based on the amount of the mortgage already paid off. The mortgage, in these cases, is renegotiated with the rate on the unpaid balance left as is 
or increased. The rate on the new loan portion will reflect current rates and the combination is usualiy rolled into one new monthly rate, enabling the borrower to pay off the mortgage and the loan at the same time.

Home Improvement Loans: These loans are available almost everywhere. The term can be short or up to fifteen years and the amount can be up to ten thousand dollars. Home improvement loan rates exceed mortgage rates as lenders are allowed to discount the interest in advance or add the interest on to the principal over the life of the loan. The greatest utilization of home improvement loans would be for low dollar amounts in cases where the utilization of a mortgage instrument would call for renegotiation with its added renegotiation costs. In such cases the home improvement loan, even with a higher interest, rate, might be less costly.

Borrowing Against Existing Savings Accounts: This method of borrowing was discussed in connection with commercial banks. A point to be added is that the borrower continues to collect interest on his passbook while he is paying interest on his loan. As a result, his effective loan repayment is quite small; as the rate of interest charged is generally one and one-half percent above the rate paid by the association for the savings account.

Second Mortgages: Second mortgages can be used when the borrower does not wish to refinance under his first mortgage. Most S\&L's are required to hold a first lien on the property in order to expand a second mortgage. Rates are generally higher and maturities shorter than on first mortgages. As a result, second mortgages are not as advantageous as an advance under a first mortgage. However, they are usually more desirable than home improvement loans, especially if the amount involved is large.

Variable Rate Mortgages: The interest rate under variable rate mortgages (VRM) is pegged to a fixed index by mutual agreement of borrower and lender. The rate will increase or decrease with the performance of the. index, within limits on the maximum increase, which is generally two to two and one-half percent. The advantage to the borrower is that the initial interest rate will be lower than the prevailing rate by as much as one-half to one percent.

Variable Payment Mortgage: Scheduled repayments can be varied by agreement of the borrower and lender. This technique is usually used in order to provide reduced monthly payments during the early years of a loan, with increased payments occurring later in the repayment schedule. The variable payment technique might be used to lessen the impact of increased debt service due to the purchase of SWECS technology.

Balloon Payment Mortgage: Actually, this is a variation of the variable payment mortgage with lesser monthly payments being offset by a large payment (balloon) being due at the end of the mortgage term. This is a good device if the borrower knows that he will have sufficient funds at the end of the mortgage period. 
Graduated Payments: This technique operates on a fixed interest rate but with overall monthiy payment amounts increasing periodically on a prearranged basis.

There are other techniques that are available as well büt the ones listed above have the best applicability for potential SWECS consumers.. Schemes involving deferred or reduced interest plans are not popular with lenders as such plans interrupt the cash flow of the lending institution: Most lenders must, by regulation include some partial amortization 'in 'their loan plans.

- Financing the Buyer or Financing Technnlogy?

The Ila in element that must be remembered about loans to consumers of - a product is the creditworthiness of the borrower. The purpose of the loan and any unknowns about the product or its performance are considerations;" but if the borrower's credit history indicates a capacity to repay tlie luali, the purpose of the loan becomes secondary. This is important to understand in determining what barriers exist or do not exist in the buyer area of commercializing SWECS technoloqy.

- Buyer Considerations

Before investing in any energy modification for a home, the homeowner will weigh the length of time it will take to get his initial investment back through reduced monthly rates for traditional power. One obvious consideration is the rate at which the cost of traditional sources of power will continue to increase. However, another consideration of perhaps greater importance is whether the homeowner will realize his investment within the time span that he occupies his home. While individual cases vary, the average life of a mortgage is between seven and eleven years. That time frame is the payback period in which the new'technology must be assessed.

Turnover rates of housing must be examined as well as average mortgage life spans, especially in areas most available to SWECS technology. Turnover rates provide more specific mortgage characteristic information than average mortgage life spans and also indicate the frequency of new ownership, a point which may provide a particularly auspicious time for applying SWECS technology.

Finally, many potential consumers of all alleriale eneryy techinologies, including SWECS, feel that over time, the quality of the products will improve and that eventually the unit costs will go down as production is increased. A fear among mortgage customers is that if they wanted to sell their property in the future they may not be able to realize their. investment, as a potential buyer may not want to pay for older, more expensive technology, when newer, less costly options are avaitable.

Certainly, there is no trouble in defining a market for SWECS based on locations not served by traditional sources of power and that lend themselves 
to SWECS, in terms of climatic conditions. However, it is doubtful that such a market could sustain an industry, albeit an infant industry. At some point, market conditions must include alternatives. The alternatives may be traditional sources of power or other competing sources of alternate energy. In these cases; the consumers' decisions will be based on a variety of factors, including:

0 The state of the technology (quality, price and service).

o The initial cost of the technology.

- Cost considerations for existing energy sources.

- Length of pay-back period for initial capital outlay.

o Likelihood of realizing a return on investment during life of the mortgage.

Many of these factors are extremely variable but the fact, in itself; has to be a key consideration in defining the SWECS market today. Given such a fluid state, it is essential to consider a:variety of consumer financing techniques that offer answers in a range of situations and locations. 
The financial problems of smali wind energy conversion systems firms can be illustrated by excerpts from a "parable". offered by: Dr. ATan Burris, President of Alron: Industries; Inc. of Rochester, New York. This recitation was part of a statement presented at SEC hearings on :smal.1 business held in 1978. While it may be an overstatement, this parable does illustrate the problems facing SWECS manufacturers.

The hypothetical story involves an entrepreneur with an invention that could save twenty percent on homeowners' fuel bills.

"Try to imagine yourself in this dilemma--you have a fantastic idea and say $\$ 30$, 000 in savings which won!'t even. support you personally for long after you quit your present job to start your business, not to mention providing the $\$ 150,000$ you need to develop and patent your product and to manufacture and sell enough units to begin to show a small profit: Further, try to imagine that you don't have a single wealthy friend or relative eager to back you: You also discover that everyone thinks your idea is just pie in the sky without something more tangible like an office and operating hard: ware. You.finally persuade four friends to invest $\$ 5,000$ each despite their reservations about buying stock they can't legally sell.. You quit: your boring job, incorporate your new company, and set up shop in shabby rented quarters. Congratulations, you are now your own boss! Some unanticipated technical problems develop which threaten to stop you, but you finally solve them. You build a prototype--it works! You apply for a patent. You sell a few handmade units to friends who are enthusiastic about the performance of your product. You have the world by the tail except for a 1 ittle problem-even though your wife has gone to work to support you--you only have $\$ 3,000$ left in the bank account. You need money to improve the product, buy production machinery, build an inventory and market the product. Your original investors have empty pockets. You ask all yuur friends for ldeas on how to raise more money, you check out their ideas and here is what you learn!

"Bank: The banker asks you to prove you can pay back the loan and asks for collateral that can be liquidated for more than the value of the loan. He doesn't consider your $\$ 45,000$ house and $\$ 2,000$ car adequate collateral for a $\$ 100,000$ loan and is not impressed with your glowing projertions nf future profits. He suggests you see the SBA for a loan guarantee. . . .

"SBA: There are three problems with the SBA. First, they have almost the same requirements as the bank and as you don't have a going business they aren't interested. Then if they were interested, the red tape would take six months and you would be broke long before that. And last, they would require that you and your wife personally guarantee the loan so that if your business goes belly up, you would not only lose your $\$ 30,000$ investment but also have to go bankrupt and possibly lose your home, car and anything you own, and be reduced to poverty. You don't find this prospect appealing. The SBA suggests a venture capital company. . . . 
"Venture Capital Company: After talking to a few, you learn that they also have almost the same requirements as the bank and aren't interested in anything that is risky. and not already profitable; except possibly something sexy like computer accessories. They are sorry to hear that your invention wouldn't save computer power. If they were interested, they would loan money at a high interest rate with a lot of restrictions on how you ran the company, if you gave them an option for a controlling stock interest for. their trouble. In other words, they will only supply equity capital after you are very successful and it's time to. cash in. They also- want a personal guarantee of the loan. They suggest contacting the Energy. Department of the government as your invention would save energy. . . .

"Federal Department of Energy: You can't afford the trip to Washington, so you write a letter. You receive an envelope full of press releases and brochures. You try to telephone and finally contact someone who explains that the government doesn't provide capital to businesses as this would be immoral and that all the energy research money for that fiscal year has already been committed to contracts with Lockheed and Consolidated Edison. However, they do have a small business incentive program which will provide 90 percent of the money for testing your invention at the National Bureau of Standards, Department of Commerce. The idea is that once you have a favorable test report, you will be able to attract customers and investors. After five months of proposal writing, the grant is approved. You contribute $\$ 1,000$ worth of product to be tested as your share and the Department of Energy provides the other $\$ 9,000$. Unfortunately, you can't afford to fly to the National Bureau of Standards to make sure your equipment is properly used so when the report is issued a year later it says that your invention will increase fuel costs 20 percent instead of decreasing 20 percent, and that in any case it would be much better for homeowners to heat with steam piped from nuclear power plants. In the meantime, one of your friends suggests that you get assistance from the Economic Development Commission of your state which is advertising incentives to bring business into the State. . .

"State Economic Development Commission: You find that the State is only interested in luring prosperous estabTished companies into expanding, or moving into the state, not providing equity capital to develop a new enterprise in the state. If your financial history demonstrates that you will be able to pay back the money and you can pay $\$ 100,000$ down, the state will provide low interest financing on a million dollar building and waive real estate taxes for five years. They might even finance your machinery, but you don't get a dime for working capital. Once again you learn that you can get financial help only if you can prove you don!t have to have it.

"The cycle of frustration does not necessarily end at this point. If you seek to raise capital through the issuance of stock in your business, you run up against several harsh realities. You must register your stock before you can advertise or sell it. However, the front-end costs for the preparation of a prospectus, a financial audit, preparation of financial. statements and additional-costs could require an outlay of funds equal to the amount you hope to raise." 
The problem identified in the above parable; the need to provide collateral in excess of the loan request, including personal guarantees, the need to Evidence an existing business, time delays and red tape, up-front costs, the demand to turn over most of your business in exchange for equity capital are all too real.

For the entrepreneur who is trying to develop a business manufacturing SWECS technology there are innumerable problems: covering the following general areas.

\begin{tabular}{|c|c|c|}
\hline Einancial: & $\begin{array}{l}0 \\
0 \\
0\end{array}$ & $\begin{array}{l}\text { Capital fnrmation } \\
\text { Cash-flow } \\
\text { Corporate/product development } \\
\text { transitional stages }\end{array}$ \\
\hline Management: & $\begin{array}{l}0 \\
0 \\
0 \\
0 \\
0\end{array}$ & $\begin{array}{l}\text { Organization } \\
\text { Incorporation } \\
\text { Corporate growth } \\
\text { Personnel } \\
\text { Corporate/product development } \\
\text { transitional stages }\end{array}$ \\
\hline Regulation: & $\begin{array}{r}\cdots \\
\quad 0 \\
0 \\
0 \\
0\end{array}$ & $\begin{array}{l}\text { Cost } \\
\text { Time } \\
\text { Direct impact } \\
\text { Indirect. impact }\end{array}$ \\
\hline Tax: & $\begin{array}{l}0 \\
0 \\
0\end{array}$ & $\begin{array}{l}\text { Payment of } \\
\text { Rel ief from } \\
\text { As incentives }\end{array}$ \\
\hline Growth: & $\begin{array}{l}0 \\
0 \\
0 \\
0\end{array}$ & $\begin{array}{l}\text { Financing growth } \\
\text { Product development } \\
\text { Sales } \\
\text { Personnel }\end{array}$ \\
\hline The Market: & $\begin{array}{l}0 \\
2 \\
0\end{array}$ & $\begin{array}{l}\text { Define } \\
\text { Create } \\
\text { Penetrate }\end{array}$ \\
\hline
\end{tabular}

From these general areas come the financial issues that directly and indirectly impact on SWECS manufacturers. In this case, the term indirect does not necessarily mean less of an impact. It refers instead to impact on external elernents relating to the ability to operate and grow as an enterprise as opposed to impact on the company directly. In many cases the indirect impacts may have as great:a significance as the direct ones. For instance, an indirect impact may be one that directly affects a finañcial institution and as a result affects the ability of a SWECS manufacturer to secure financing. The process may be indirect but the result is felt most directly by the SWECS manufacturer. 
The financial issues that directly affect SWECS manufacturers are simple and straightforward. They are:

- Not having enough capital

- Not knowing how to secure capital

o Not knowing precisely how to translate an idea into a business

These issues exist totally independently of the indirect issues that affect the total marketplace in which SWECS manufacturers operate. While tax legislation and inflation have a profound effect on SWECS manufacturers, their more immediate problems have to do with how to get working capital to meet a payroll or pay the rent. While this report gets into the "who, what, when, where and why" of each of the above three issues, it is important not to lose sight of how basic the issues and the needs of SWECS manufacturers are today. The chart on the following page is intended to act as a road map of a small business corporate/product growth. Specific financial needs and sources for each stage of development are presented, as well as a variety of facts that indicate the comparative status of small business growth progressions. Again, it is important to understand that the SWECS industry is; by and large, at the beginning of the corporate/product growth process. In this sense the chart and the issues discussed in this section do act as a road map, charting the future, not just verifying the present.

The matrix is designed to illustrate how each stage of corporate/ product development requires a different type of capital. In this sense, the section denoted by Roman numeral III, Principal Financing Sources, is of , prime importance whether the reader is a SWECS manufacturer or government official. The other descriptive classifications (phase, level: of activity, revenues, company characteristics and applicable government regulations) serve to more fully characterize the nature of a firm at each stage of corporate/product development.

The Financtal Resuurce section presented earlier in this report ind icated the type of financing (debt, equity, short-term or long-term) that each institution provides. Matching the descriptions of the financial institutions with the matrix, it is clear that commercial banks and other lenders fill the need for short-term, temporary financing. This is usually done through loans granted for a specified period of time. These shortterm, temporary needs usually occur at the beginning of the corporate/product development growth progression, as shown on the matrix. The limitations on this type of capital availability depend on prevailing interest rates and on the size of the equity base of the company. This last limitation often points a successfully growing young company toward more longterm, permanent financing.

The first step in seeking growth capital is usually the realization by a developing company that it cannot provide such financing internally and 


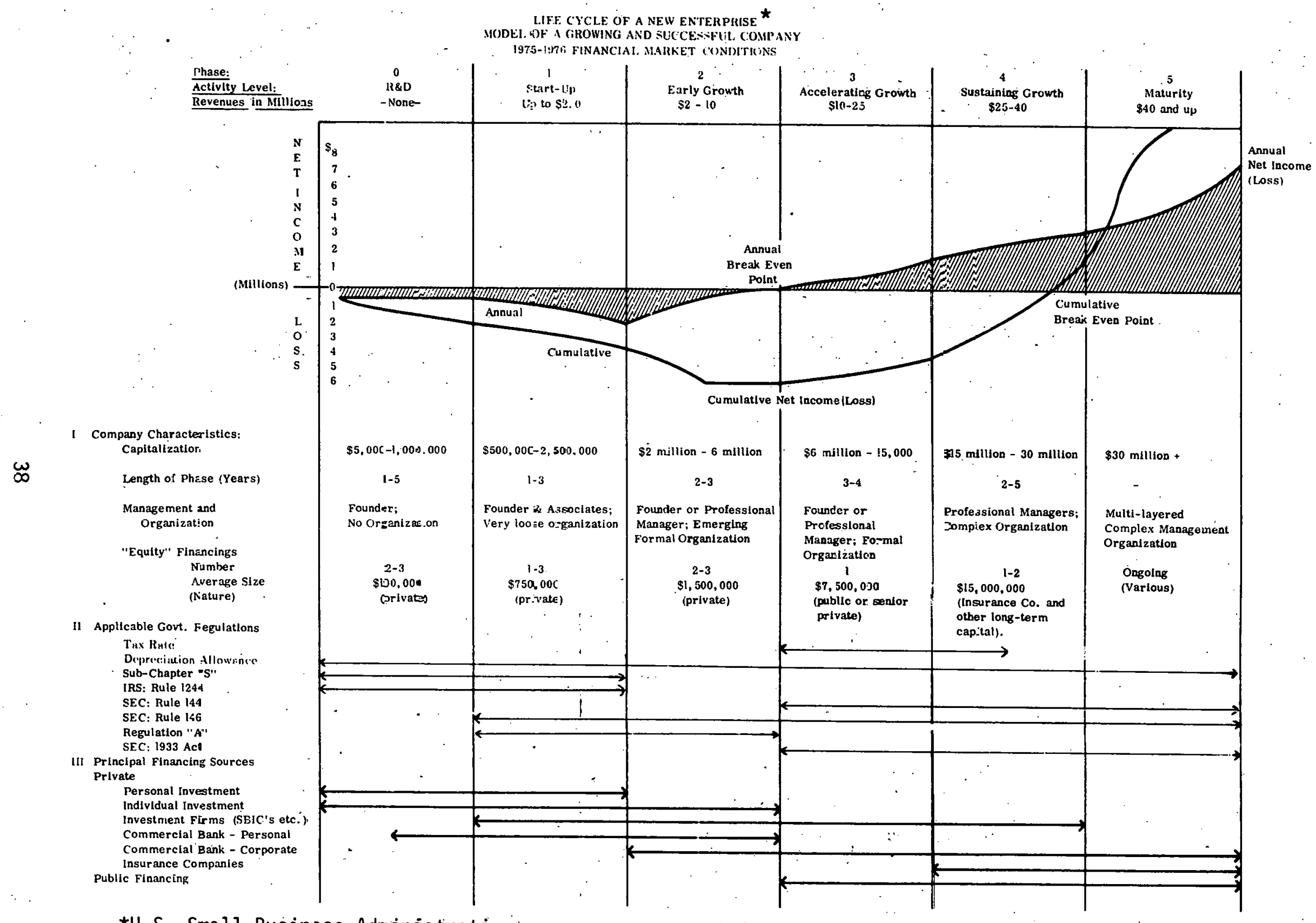

*U.S. Sma11. Busiriess Administration 
must seek external aid. Venture capital groups usually provide such necessary capital (described as risk financing) at this stage of corporate/ product development. The matrix shows that such groups (defined as investment firms) enter the picture, as this report has indicated, after personal investment and initial personal loans from commercial banks have been utilized. The function of venture capital becomes critical if an emerging company is to have the opportunity to grow and enlarge its equity base. Generally speaking, the longer a firm is in business the more likely it is to succeed. Continued operations tend to lower the risk of investing in it. The lowering of risk in turn enhances the company's success, allowing for its equity base to increase. Once a company's equity ba'se increases, the easier it is for that company to meet its financing needs, either through its own earnings, the selling of additional equity, or by borrowing in the debt market. The essential thing for a company to do is to. continue to operate in order to allow the growth cycle to continue. The role of venture capital at the stage described is critical, as an emerging company. cannot generate its own capital needs and therefore must seek outside help.

Venture capital as a link between personal financing and public financing is particularly critical today as the gap to be "linked" or "bridged" must be sustained until revenues of ten million dollars are realized. The matrix shows this fact very clearly. Unl ike the "go-go" market of the 1960 's, when it took very little revenue to enter the public financing market, today's conditions clearly show that a company must be established and have compiled a demonstrable track-record before public financing (public stock offerings) can be contemplated. The company characteristics on the matrix show what must be accomplished by the point where the public financing line begins.

The length of time that the venture capitalist must commit his resources has made the actions of this segment of the financial community cautious. The pay-off for the venture capitalist (the point where he liquifies his investment in the company) comes when the company is able to put together a public stock offering ("going public"). If the company cannot successfully put together such an offering, the pressure on the venture capitalist to liquify his investment will usually force the company to merge with another firm. This report clearly shows that the problems and costs of "going public" today are enormous. As a result, there is a tendency of many venture capitalists to initially regard a potential client investment situation in terms of whether the company's product can fit into the existing product 1 ine of some larger firm. Such merger-potential assessments can have a definite impact on a growing company that seeks not only. to develop a product, but to develop a company to sell and service the product.

The prospect of succeeding only to lose control of his or her idea and product may not be heartening to all SWECS manufacturers. It is important that these manufacturers; as well as policy-makers, have as clear an idea of what confronts them as possible. The matrix is not designed as a "magic path" that will guarantee commercial. success for any SWECS manufacturer. Instead, it is designed to show specific critical choice points in financing corporate/product growth. These points recessitate decisions by the 
manufacturer. If the manufacturer has foreknowledge of these decision points and what he can do to best prepare for them, there is an increased likelihood that the corporate/product development process can proceed uninterrupted.

The specific financial issues facing SIIECS manufacturers that are detailed above are somewhat timeless as they face all new emerging business and have always done so. What does vary, however, are the conditions that affect the entrepreneur's ability to secure capital and to continue to grow, once he does know how he wishes to proceed with his business plans. The conditions vary according to the conditions of the general economy, the tax and regulatory climate, and conditions in the marketplace.

In order to totally understand the financial issues facing SWECS manufacturers, it is essential to understand the general economic, tax, regulatory, and market conditions that have existed since energy conditions have stimulated the development of alternate energy technologics. The Backaround section of this report mentioned general conditions that individually and collectively contributed to a lessening of capital availability for all small businesses in the past ten years. During an examination of these issues it is important to keep SWECS manufacturing in context. As the introduction pointed out, SWECS manufacturing must be considered:

- As part of the sector of new technical industry

o As part of the whole of small business enterprise

o In the context of the time frame that national energy policy has spurred alternate energy development.

The Background went on to rightly point out the importance of new technical businesses in the United States in terms of employment, sales, and income tax revenues and return on equity investments. The Background also pointed out the problems small businesses have had in raising funds in the equity market, caused by a combination of disincentives toward saving and rising costs of securing public equity funds. The following discussion examines factors that have threatened the positive role that new technical enterprises such as SWECS play in the economy. At the same time, this discussion will examine factors that affected the availability of funds in the capital marketplace.

\section{Inflation}

Analysts generally agree that the financial position of business has undergone a steady decline during the past decade. Inflation has caused a major shift in meeting financial requirements. Normally, corporations have relied on retained earnings and capital consumption allowances to meet twothirds of their financial requirements for investment. However, inflationary forces have caused the ratio of internally generated funds and externally generated funds to change dramatically. By 1974, fifty-five percent of corporate financial needs for funds were being met externally. Over eighty 
percent of the increase in long-term corporate funds during the past decade came from debt rather than equity offerings. The result was a doubling of corporate debt to equity ratios. The shift to external debt funding was paralleled by a shortening of the average maturity of corporate debt. This in turn meant that debt had to be refinanced more frequent1y, thus increasing the exposure of corporate financial conditions to sudden shifts in economic and credit conditions. Such destabilizing conditions increase risk as well as expected return on capital when potential investments are considered.

Another factor affecting capital formation during the past decade has been the cost required to meet the introduction of new environmental and safety regulations. Corporations are required to spend additional sums to comply with the regulations. However, there is no expectation of increasing revenues as a result of increasing production costs. Varying interpretations of new regulations have created an atmosphere of uncertainty which in turn increases risk. The result is a feeling that the pre-tax rate of return must rise before new investments will be made.

Liberalized depreciation allowances and investment tax credits have been offered as ways to offset the impact of higher taxes in relation to real corporate profits. However, a sustained period of inflation distorts the measure of taxable profits because the revenues in current dollars have lesser real value and are being compared with historical costs measured in undepreciated dollars. The impact is again to reduce the level of investment by business.

But what about smal1 businesses 1ike SWECS manufacturers? Inflation impacts on small business in the same way it impacts on "Corporate America," except more so! The impact of inflation may be the same regardless of company size but the burden is disproportionately heavy on the small business as its means of absorbing the inflationary impact of spiraling costs and prices is far more limited than larger business entities. Inflation presents a particular double danger to the small businessman as it not only heightens the capital needs of small business, but increases the costs of meeting those heightened needs as well.

Small business has been hit by the remedies to inflation as well as by inflation itself. The governmental response to inflation is usually a tightening of credit which results in higher interest rates. Again, the burden of this impact hits small business disproportionately. Usually they are not in a position to absorb or pass on to customers the increase in interest costs. Even if they could absorb the costs, the real crunch comes in finding available capital to borrow: The dependency of small business on borrowed funds makes the remedies to inflation as bad, if not worse, than the impact of inflation itself. An earlier section of this report detailed the borrowing scenario of a new company seeking financing. The scenario pointed out the progression of short-term notes that a small business depends on: The total dependence on such borrowings and their impact on the company's debt-to-equity ratio when coupled with a diminished availability and higher cost of funds can be crushing to so fragile a structure as the infant SWECS business. 
$\underline{\operatorname{Tax}}$

A second factor affecting capital formation for SWECS technology is tax policy. Over the past decade tax policies have encouraged consumption rather than savings by taxing income on savings as well as on initial income. As a result, investment has been curtailed as savings are a foundation for investment. The curtailment on investment has, in turn, had a negative impact on economic growth. The role which new companies play in economic growth means that tax policy has a major impact on small business.

Some individuals feel that the impact of major tax measures on small business have been offset by other tax changes affecting depreciation allowances and investment credits. Such measures may aid large businesș, but do little to alleviate the burdens of small business. Large companies, being more capital intensive have a larger proportion of equipment in the productive process. Also, tax credits are most beneficial to companies already carning profits. If a company is eariining $1 \mathrm{illle}$ profft, $1 \mathrm{t}$ cannot receive much benefit from measures designed to reduce the tax liability on profits.

Tax policy has affected the ahilit.y nf new companies to form capital in three major ways:

- Lessened capital availability

- Raised the cost of securing available capital

- Modified marketplace behavior.

The spirling tax rate on capital gains over the past ten years has impacted on all three aspects of capital formation. Any increase in the capital gains tax reduces the incentive of individuals to invest in equity of companies. Such a modification in marketplace behavior reduces the amount of available capital to be raised by entrepreneurs. A reduction in the availability of capital makes the cost of the scarce capital available more expensive. The consequence of this cycle on new businesses, as mentioned earlier, is the fact that between 1973 and 1978 American households were net sellers of equity investments in the amount of twenty-five billion dollars!!

The withdrawal of individuals from the marketplace hits new and small business especially hard. As stated in the Background section, in 1969, for companies under tive million dollars in networth there were 548 offerings, totaling almost one and one-half billion dollars. The number of offerings and total funds raised declined annually to the point where in 1975 there were just four offerings totaling a little over sixteen million dollars.

The withdrawal of the individual investor from the marketplace increased the importance of the institutional investor in two ways. On the one hand there was a direct shift of individual investments away from equity issues; on the other hand, many individuals shifted from a direct investment to an indirect role by participating as employees in pension funds and other 
emerging alternate investment avenues. The result was that equities not only lost a substantial amount of available capital but they were then forced to compete with new competitive investment opportunities.

The emergence of institutional investment has had unique impacts of its own on the ability of new companies to emerge and grow. With large pools of capital available for investment, small issues had to compete with large investment possibilities. This competition has worked to the disadvantage of small companies as the Department of Labor Guidel ines covering the 1974 Employee Retirement Insurance Security Act (ERISA) indicated that portfolio managers would be held personally responsible for their portfolios on an investment-by-investment basis, as opposed to the management of the portfolio as a whole. The potential for litigation was obvious and resulted in portfolio managers limiting their investments to blue chip stocks and other low risk opportunities. The effect of such actions was to exclude huge pools of liquid capital from any venture seen as the least bit speculative. In these circumstances "speculative" included new start-up companies and most of the whole of small business. The impact of the ERISA Guidelines would have been great at any time but following in the wake of other factors detrimental to the viability of new businesses it was devastating.

The Department of Labor has recently revised the ERISA Guidel ines and there is some indication that there has been a positive effect in the marketplace. The changes meant that a pension fund portfolio manager could no longer be held personably liable for the performance of each individual investment in the portfolio, provided the manager followed specific Department of Labor Guidelines. Those guidelines (consideration of the diversification of risk, liquidity and current return relative to anticipated cash flow, and projected return relative to funding objectives) if followed constitute compliance with the law and virtually negates potential litigation against the portfolio manager.

However, for a period of five years liquidity was withheld from startup ventures. A mere few percentage points of the totality of pension funds would be enough to make a decisive impact on all new business, let alone SWECS, or even all alternate energy technologies. The coincidence of the 1974-1979 time frame is especially relevant to the SWECS industry as it was during that time frame that many of the SWECS manufacturers went into business.

Another tax issue which directly affects new businesses relates to stock options. The ability to attract good talent to a new enterprise is often based on the potential in the future rather than on the present situation. New businesses, starved for capital cannot offer high salaries as an incentive for attracting key personnel. However, they can offer stock options as a form of compensation. Unfortunately, at the present time, there is no incentive in this method as the Tax Code treats the employee recipient's gain at the ordinary income tax rate at the time the option is exercised. This means that he is taxed on an unrealized gain. The lack of liquidity in the stock may actually force the employee to have to borrow money to pay the tax. The valuation of stock and an option to buy stock in 
closely held businesses creates difficult tax problems. Valuation of stock and fair market value for an option can become disputed issues with the Internal Revenue Service. Even if the new business entrepreneur wins the dispute, the cost and time spent resolving the issue may be too great.

A final tax issue that impacts directly on the unique character of small business is the matter of depreciation for purchases of machinery and equipment. The average period of depreciation is currently ten and onehalf years. Taking into account current inflation rates, the value received from depreciation during the tenth year will be worth about twenty percent of what was invested. In addition, replacement costs at the time will cost about eighty percent more. Ten-year time horizons for any new business are not realistic and clearly there would be great value in accelerating depreciation. Such an acceleration would be especlally helpful in light of the fact that approximately eighty percent of all businesses purchasing equipment in any one year spend less than two hundred fifty thousand dollars.

$\underline{\text { Regulation }}$

Regulations that have a direct impact on a business, such as OSHA, were. mentioned earlier in this report. Here the discussion is directly related to regulations on the institutions and methods of raising and forming capital.

The major consequence of regulation for new and small businesses over the past decade has been the effect regulations have had on the cost of raising capital with a consequence being that costs have risen so dramatically so as to make capital unavailable in many instances.

There are various reasons for increases in the cost of going public, including issues already discussed in this section of the report. In addition, there has been a trend of acquisitions and mergers in the bruker-dealer investment community. That has been going on for several years. Many of the firms that have ceased to exist were regionally oriented. The consequence of a contraction of such firms was a lessening of potential funders of small local or regional firms as well as a lessening of places where individuals could invest in such firms.

As larger broker-dealer firms have come to dominate the marketplace the number and kind of investment choices has decreased. Large investment firms are not generally as interested in smaller issues and, even in cases where there may be an interest, the entrepreneur must pay more to cover the larger uverhed carricd by the larger firms. Ihe increased uverhead has a ripple effect as the larger investment houses retain large accounting firms and legal practices to handle those specialized parts of their business.

Another considered reason for the contraction of the broker-dealer community was the introduction of fully negotiated commission rates and the simultaneous abolition of standard brokerage fees on May 1, 1975. There is debate over the full effect of these actions but a couple of facts are clear. First, since the institution of negotiated commissions almost every major institution or research firm has ceased to exist as an independent 
entity. Second, the securities industry association maintains that since commission rates became unfixed the top twenty-five securities firms have continued to increase their share of the market, as measured by commission revenues. Those twenty-five firms hold about a seventy percent share of the market, with the other thirty percent being divided by three thousand other broker-dealers.

The number of broker-dealers decreased at the same time that the costs of going public increased. As was noted in the Background section, the fixed costs of registering with the SEC increased in the past decade from an average of between fifty and seventy-five thousand dollars to between. two hundred and two hundred and fifty thousand dollars. In his testimony before the Senate Select Committee on Small Business on September 21, 1978, Mr. Will iam Hambrecht stated that of the initial public offerings completed in 1977 the average cost was two hundred and eighteen thousand, six hundred dollars. This figure did not include underwriters spread or marketing costs. The break-out of the two hundred eighteen thousand, six hundred dollars was as follows:

$\begin{array}{lll}0 & \text { Legal fees } & \$ 67,600 \\ 0 & \text { Printing } & \$ 65,200 \\ 0 & \text { Blue Sky Laws } & \$ 19,300 \\ 0 & \text { Accounting fees } & \$ 43,700 \\ 0 & \text { Registration and miscellaneous } & \$ 22,800\end{array}$

These figures show that the degree of detail in required registration procedures and the frequency of required reporting results in such high costs. Until recentiy, other factors increased the costs as well as the necessity of having to come to Washington, D.C. during the registration period.

Some recent changes in the Securities and Exchange Commisston requirements have addressed these problems. A new and simplified registration form, the $\mathrm{S}-18$ has been introduced to speed the registration process and decrease the costs. This is done by enabling the entrepreneur to register at a regional SEC office instead of having to come to Washington, D.C. and by limiting the number of audited statements a business has to file. This new form is accompanied by the establishment of a new office of small business policy at the SEC.

These new actions by the SEC serve to highlight an additional key regulatory problem. Each state has its own securities legislation, regulations and enforcement structure, which can act separately from SEC action. The securities laws of the states are referred to as "Blue Sky Laws." Depending on the state in question, it is possible that all efforts by the SEC to hasten and reduce the cost of registration may be offset by state requirements that continue to require what the SEC no longer denlarids. 
States are generally described as either "merit" or "disclosure" states. Disclosure states base their philosophy on the concept that full disclosure of the risk of an investment is sufficient for protecting the investor. Merit states base their philosophy on the concept that some ventures, regardless of disclosure, may be too speculative and should be prevented from reaching the public.

Some action has been taken to bring the federal and state systems more into line. The North American Securities Administrators Association and several state commissioners have taken steps to replace existing "Blue Sky" exemptions from registration for listed securities with a uniform exemption from registration. As a result, the quality of the security becomes the determining factor, not the marketplace.

The uniform exemption has special significance for over the counter stocks not on listed exchanges (most new emerging technological issues including alternate encrgy issucs fall into this category). Qual ily slucks not listed on a national exchange may be held up during state registration simply for lack of a national listing. This can cause added time and money delays. The concept of a uniform exemption could nverrnme surch difficulties.

The matter of state securities law in terms of SWECS manufacturing takes on a special significance when an examination is made of the states where the most money has been raised for alternate energy. Colorado, New York and New Jersey have all raised a great deal of money for alternate energy issues. Each of these three states is a "disclosure" state, meaning that the state security registration procedures are more flexible than their "merit" counterparts. It is true that each of these states is a particular financial center but one of the reasons for that status has to do with the state securities law.

The etates and their securities laws are a focal point for potential action to aid the SWECS industry now that the SEC has begun to move to recognize the particular problems of small business. The difference between state investor protection philosophies can be seen in comparing the state statutes covering securities for a "disclosure" state, such as Maine, and a "merit" state, such as Wisconsin. Even in reviewing these regulations, it must be remembered that much of how a state acts in this area is a result. of how the state securities administrator interprets the regulations. As such, it is important, and perhaps sufficient to deal with such administrators, rather than seeking legislative action in states to deal with the ijsuc of "Blue sky" laws.

Major issue areas have been broken out in the above section in order to focus on the genesis of particular problems. In the process of segmenting issues, however, it becomes clear how interrelated such issues of inflation, tax and regulation are. In fact, the interrelated nature of the issues becomes an issue in itself as they all feed into one another. The relationship of these issues to each other also illustrates how deceptive it is to believe one single type of solution may solve the financial problems facing SWECS manufacturers. 
The full impact of all the discrete issues can be seen when they are seen in juxtaposition: a basic tax structure providing disincentives for savings as evidenced by the rise in capital gains taxes beginning in $1969 \rightarrow$ aiding to the withdrawal of the investor from the investment marketplace $\rightarrow$ which in turn increased the importance of the institutional investor $\rightarrow$ but increasing such importance at the exact time that federal guidelines were moving such investors away from new and small business issues $\rightarrow$ at the same time consolidation in the marketplace was increasing the importance of the larger broker-dealer which in turn $\rightarrow$ added to the already spirling costs of "going public" brought on by inflation and increasing regulatory burdens. The rising costs in turn $\rightarrow$ decreased the availability of capital for new and small businesses.

In the new and small business sector of the economy, rising costs do not simply select out less efficient participants but may select out all participants. Capital may exist regardless of price but at a certain price it is out of the reach of new businesses and, therefore, unavailable.

Federal Funding for R\&D and Federal : Procurement

These two topics have been the subject of separate analyses of their. own but do warrant mention as they add to the financial woes of new businesses including SWECS manufacturing. In the recent past, federal funding for research and development (R\&D) has declined as a percentage of Gross National Product (GNP). At the same time existing support has been aimed at a relatively small number of firms, universities and federal laboratories. It is ironic that direct support for applied research has grown in these institutions, while decreasing in the innovative sector of the economy, namely, small science and technology firms.

Federal procurement has also attracted new and small business adversely. Federal guidelines and specifications make it impossible for new and small. businesses to compete. The federal government is such a large purchaser of goods and services that it could single handedly create a market for SWECS technology. By precluding new business from the federal marketplace the government not only dampens innovation but perpetuates its own system inefficiencies. The innovations that new and small businesses bring to the federal purchaser could lower procurement costs and help provide new products which in turn could create new services. 


\section{RECOMMENBATIONS*}

This report has shown that there are two levels of problems requiring two levels of recommended action.
Problems
Recommended Action :-
- Industry/marketplace
Pol icy changes
0. Individual company
Practical/how to ...

It would be easy to focus on the industry and marketplace as there are numerous issues relating to inflation, tax and regulation that can be dealt with by specific recommendations. It would also be easy to forus, on these larger issues as they address the future and indeed the hope of successfut SWECS commercialization. Unfortunately, to 1 imit analys is to the industry and marketplace totally ignores the state of SWECS manufacturing as it exists today. The current status of SWECS manufacturing is stark and quite harsh. The individual businesses are mostly in their infancy, struggling to achieve a legitimate status within the marketplace. It would appear that achieving such status would be made easier by the federal government's stated policy to use alternate energy technologies in helping to meet the nation's energy problems.. However, statement of such policy has added a pressure by way of prematurely raising expectations about the role of. SWECS and other alternate energy technologies, beyond what they can realistically produce today. The desire, and in this case the expectation, is to have the normal evolutionary development of an industry accelerated to meet a national goal. The marketplace is not designed to provide the initial push in such a process. That initial push must come from outside the marketplace and speed the entry of the industry into the marketplace where the forces of the marketplace can then carry out their. part in the development process. Statements of policy and existing research, development and demonstration programs are not sufficient extra-marketplace activity to initiate the process, and unless and/or unt $i$ l committed government action as interpreted by the marketplace is initiated, the SWECS industry will be whipsawed by both the hope and promise of unrealizeable expectations. The simple truth is that success for the SWECS industry today is dictated more by political contact with Washington than by the economics of the marketplace. In this context the American Wind Energy Association can continue to act as a proponent of the SWECS industry in the political arena of Washington, seeking to secure those direct federal funding actions necessary to insure SWECS entry into the marketplare.

In the meantime several things can be done to assist the SWECS manufacturer to cope and, hopefully, progress on his own toward becoming an

* There is no prioritization to any of the Recommendations as the subject matter and the Recommendations do not lend themselves to such an ordering. 
established business. Each of the following recommendations is aimed at focussing SWECS manufacturer's attention on "appropriate financing," or the right financing for the right stage of corporate development.

- Develop a clearinghouse of SWECS product information. This report recognizes that efforts in this direction are already. underway by several organizations in government and in the SWECS industry. These efforts should be continued and perhaps consolidated so that the public can understand the technology better and have better and more precise information in terms of being potential purchasers. Product and industry credibility must be established as an answer to raised public expectations.

- Develop a SWECS business consulting service to provide authorized business advice on a totally confidential basis. SWECS manufacturers like all new business entrepreneurs are very reluctant to give out any information on their own product and company. But without information there can be no helpful advice. In some ways such a program would be the financial equivalent to the technological testing program Rockwell runs at Rocky Flats. The key to this program is that the process must insure confidentiality, perhaps through the auspices of the government and the information must be free, subsidized by the government. This is a direct way for the government to provide access to the marketplace for the SWECS manufacturer.

- Develop and produce a television cassette information package that would contain a direct "what's needed" and "how to" discussion with the various types of financial people who are and will be in a position to lend funds to SWECS manufacturers. Within a half-hour cassette actual lenders can tell the audience specifically what they as lenders need to have and what potential borrowers need to know in order to secure funding. This visual aid technique contains more information presented more graphically than any written piece possibly could. The information packet is also flexible ennugh to be used in large groups, small groups, and by individuals.

Develop a theoretical optimal distribution channel for SWECS technology. This is not a market study done to define what the commercial potential of the technology can be but rather it is a process study done to describe how to distribute the technology. This theoretical channel will actually give the SWECS manufacturer some tangible information that can be used in the structuring of his own business and marketing plans. Financial positioning and marketing together become key ingredients in developing such a distribution channel.

Each of these recommendations is designed specifically to bridge the gap from where SWECS manufacturers are today to the marketplace. Each recommendation is designed to help the SWECS manufacturer raise questions and 
receive answers to these questions regarding the day-to-day operations of his business. They also are designed to aid the manufacturer in designing a business plan for his own firm and in helping him deal with his own banker or financial resource.

The above recommendations are aimed at helping the individual SWECS manufacturer cope with an adverse environment until fundamental structural changes occur that will change the environment. The following recommendations are designed to address specific issues involving inflation, tax policy, regulation and other marketplace factors that in the long run will be the determinents of the SWECS industry's fate.

In terms of dealing with the economic impact of the interesting forces of inflation, tax policy and regulation, this report makes several recumendations. Before making them however, it is important to note recent developments that have occurred that may directly affect the SWECS industry. The tax on capital gains has been reduced from forty-nine percent to twentyeight percent. In addition, the Department of Labor has revised the Guidelines governing portfolio manager responsibility under ERISA. There is some indication that these actions have already had a positive effect on capital formation. In recent months the amount of money raised in the venture capital market has increased significantly. However, it remains to be seen if these actions can be maintained under the present period of tight credit. In addition, one distinctive feature of the present venture capital "mini-boom" is the emphasis on mergers and acquisitions as the ultimate fate of new emerging companies. While this may satisfy certain elements in the marketplace it does not aid that sector that the economy depends on for innovation, namely, new businesses such as SWECS manufacturing. Finally, the venture capital that is presentiy available is going to businesses that have already established a growth pattern. In short, what is available is expansion capital not seed capital. Taking into account these observations as part of the current business environment this report recommends:

- Permit the establishment of special tax-deferred reserves similar to those in existence for the banking and insurance industries for broker-dealers engaged in market making as a means of providing improved depth and liquidity to the markets in securities of small and developing companies.

- Further reduce the rate of tax imposed on capital gains to provide for an eighty percent exclusion from taxable income for gains on investments in husinnsses which had no more than rive million dollars of equity capital at the time such investments were made.

- Increase the incentive for investing in small business by allowing the capital gains tax liability from inves Lments in small businesses to be deferred if such gains are reinvested within some prescribed period in other new small business inves.tments. 
Provide that employees of small businesses shall realize no income at the time stock options are granted or exercised, that the gain on securities acquired through the exercise of a stock option be the excess of the selling price of the securities over their value at the time of grant and, that such ga in be recognized as a long term capital gain if the combined holding period for the option and the stock is not less than three years.

Permit greater latitude in depreciating machinery and equipment. Ten and one half year depreciation schedules must be reconsidered in the face of current inflation. The amount of money recovered during the tenth year will be worth about twenty percent of what was invested and the replacement equipment that must be purchased will cost about eighty percent more. Discussion about the available ceiling dollar figure for depreciation varies widely. Figures indicate that eighty percent of all businesses purchasing equipment in any one year spend less than two hundred fifty thousand dollars. Under such circumstances the one hundred thousand dollar figure proposed in S. 2742 [95th Congress, 2nd Session (1978)] would be fitting.

In order to tap new sources of risk capital, this report suggests that consideration be given to permitting public investment in professionally managed venture capital firms. Congress sought to do this when it developed the SBIC program as a source of venture capital for small firms. However, the intent of Congress has been frustrated by the Investment Company Act of 1940 (the "Act".) under which all publicly held SBIC's must operate. Those that do operate in this mode have largely provided investment loans to small businesses. As a result, there are no 'SBIC's registered under the Act that are true venture capital companies. The 1940 Act is also the source of the problem for the privately financed venture capital companies seeking to go public. The provisions of the Act which are particularly burdensome are those which limit management compensation, the percentage of a fund's assets which may be invested in a single company and the percentage interest in a company which a fund may acquire.

Adopt some form of limitation of liability or indemnification for attorneys and accountants rendering services to issuers making securities offerings. The roles of accountants and attorneys in the offering of securities is necessary and the cost of those roles is borne by the issuer (businessperson). The cost of these professional services has escalated as the premiums that the accountants and attorneys pay for liability insurance has increased. These increases are passed onto the customer (issuer). These increased costs and other increased costs of registration bear heaviest on small businesses. An indemnification or limitation of liability for such service-providers would spur the decrease in the rates charged for liability. 
Adopt a uniform exemption from registration to replace existing state "blue sky" exemptions for exchange-listed securities, thereby ending the cost of duplicative procedures. This is particularly important as the SEC has already made strides to facilitate capital formation for new and small business.

Have the Department of Energy determine the viability of developing a program similar to those embodying State Development Corporations (SDC) and Local Development Corporations (LDC) but specifically for the promotion of SWECS (or all alternate energy) manufacturing. Such a program could stimulate financial assistance for SWECS manufacturcrs at the state and local level. Such a program would stimulate SWECS manufacturing with in the private sector environment rather than creating a direct dependency on the federal government through the creation of direct.subsidies.

In making these structural recommendations it is clearly understood that the time involved to treat these individual propositions is great and that not all of them could be dealt with at once. However, these recommendations get to the roots of the problem. The likelihood is that these structural recommendations will be of most help when SWECS manufacturing reaches the stage of being part of the marketplace, when the problems become more a matter of growth and expansion. As a result, this report emphasizes the necessity of using facilities outside of the marketplace to propel SWECS manufacturing to the stage where the marketplace can beneficially aid the industry. A very direct and substantial infusion of capital by the federal government to the industry members is necessary to accomplish this. The form of that aid can be subsidies, loans, loan guarantees or any other mechanism that can quickly and effectively accomplish what the federal government has voiced as its own desire namely, speeding up the ability to make SWECS a commercially viable alternative, in certain cases, to fossil fuels. The specific manner in which such federal action can be most effective is a subject beyond the scope of this report, but evidence of the need has been clearly shown. 
ATTACHMENT A

REFERENCE LISTING 


\section{REFERENCE LISTING}

Blue Sky Law, Maine Securities Act, Title 32, Sub-chapter I - General Provisions, Commerce Clearing House, 1978.

"Blumenthal Calls for Action on Inflation, Taxes, Regulation to Promote Investment," Wall Street Journal, May 9, 1979.

Characteristics of Future Vertical-Axis Wind Turbines, Emil G. Kadlec, Sandia Laboratories, Alburqueque, New Mexico, July 1978.

Economic Analysis of Darrieus Vertical Axis Wind Turbine Systems for the Generation of Utility Grid Electrical Power, "Vol. I - Executive . Summary," Sandia Laboratories, Alburqueque, New Mexico, August 1979.

"Vol. II - The Economic Optimization Model."

"Vol. III - Point Designs."

"Vo1. IV - Summary and Analysis of the A. T. Kearney and Alcoa Laboratories Point Design Economic Studies."

"Economies of Scale - The Problems of the Larger Firms vs. The Smaller Ones," The Market Chronicle, October 25, 1979

"The Energy System of the Future," Edmund Faltmayer, Fortune, September 24, 1979.

"Examination of the Effects of Rules and Regulations on the Ability of Small Business to Raise Capital and the Impact on Small Businesses of Disclosure Requirements Under the Securities Acts, Securities and Exchange Commission," Federal Register, Vol. 43, No. 51, March 15, 1978.

"Financiers, Bankers, Investors," Report of The White House Mini-Conferences on National Energy Policy, May 1977.

The Financing of Small Business Corporations, U.S. Small Business Administration, Washington, D.C., October 1978.

Financing Methods Applicable to Energy Conserving Retrofits for SingleFamily Residences, National Savings and Loan League, for the U.S. Energy Research and Development Administration, June 1977.

Flow of Funds Accounts 1946-1975, Board of Governors at the Federal Reserve System, Washington, D.C., 1976.

Flow of Funds 1978 Outstanding - Preliminary, Board of Governors of the Federal Reserve System, Washington, D.C., February 1979. 
Full Faith and Credit, Secondary Participation and SBA Guaranteed Loans, U.S. Sma11 Business Administration, Washington, D.C., June 1977.

"The Government Can Help More by Doing Less," Tom Alexander, Fortune, September 24, 1979.

A Guide to Commercially Available Wind Machines, Wind Systems Program, Rockwell International, Rocky Flats, Golden, Colorado, April 3, 1978.

Hearings on Capital Formation, before the Select Committee on Small Business of the U.S. Senate, 95th Cong., 2nd Sess., Part I, February 10, 1978.

Hearings on the Future of Small. Business in Allertca, before the subcommittee on Antitrust, Conșumers and Employment of the Committee on Smal1 Business, 95th Cong., 2nd. Sess., Parts I and II, 1978.

H.R. 3981 and H.R. 3984, The Small Business Energy Conservation and Commercialization Amendments, Hearings before the Subcommittee on Energy, Environment, Safety and Research of the Cormittee on Small Business, 95th Cong., 1st Sess., Part I (July 27, 1977), Part III (December 9, 1977), Part IV (February 13, 1978), Part VII (March 20, 1978).

"House and Senate Agree on Reg. A Ceiling of $\$ 2$ Million: May Go Higher Next Year." Corporate Financing Heek, September 25, 1978.

"In Denver and Elsewhere, Stock Offerings of Some Small Firms Revive Go-Go Years," Burt Schorr, Wall Street Journal, August 22, 1979.

"Increase in Ceiling for Small Offerings Approved by Serlate," Federal Securities Law Reports, No. 767.

Investment Banking Arrangements, Patrick J. Davey, Report No. 681, The Conference Board, 1976 .

"Lack of Investments Seen Imperiling Small Business," The Washington Post, May 24, 1979.

"Market Penetration Models for Energy Production Devices and Conservation Techniques," Lloyd L. Philipson, Technological Forecasting and Social Changr. 11, 223-236, 1978.

"Market Whiz' Pessimistic Outlook for '79," The Washington Post, December 31, 1978.

Moody's Industrial Malludls, Moody's Invéstor Services, Inc., New York, $\therefore \quad$ New York.

"More Frustration for Investors," The Washington Post, January 14, 1979. 
"New Law Gives Money Managers Breathing Space," Nancy Ross, The Washington Post, July 15, 1979.

New York Stock Exchange Fact Book 1977, New York Stock Exchange, 1978.

Pension Reform Act of 1974 - Law and Explanation, Commerce Clearing House, Inc., New York, 1974.

Proceedings - Small Wind Turbine Systems 1979, A Workshop on R\&D Requirements and Utility Interface/Institutional Issues, Vol. I, "R\&D Requirements," Boulder, Colorado, February 27-March 1, 1979.

Vol. II, "Utility Interface/Institutional Issues."

Proposed Changes in the Internal Revenue Code to Restore Stock Options, National Venture Capital Association.

Prospects for the American Financial Markets in 1979, Salomon Brothers, New York, 1978.

Public Attitudes Toward Investing, New York, Stock Exchange, New York, June 1978.

Regulations, Rules of Commissioner of Securities, Wisconsin Administrative Code, Commerce Clearing House, 1978.

Report of the SBA Task Force on Venture and Equity Capital for Small Business, U.S. Small Business Administration, Washington, D.C., January 1977.

Report on the Future of Small Business in America, House Subcommittee on Antitrust, Consumers and Employment of the Committee on Small Business, H.R. Rep. No. 95-1810, 95th Cong., 2nd Sess., 1978.

The Role of New Technical Enterprise in the U.S. Economy, A Report of the Commerce Technical Advisory Board to the Secretary ur Cuinimerce, January 1976.

S\&L Fact Book 1978, U.S. League of Savings Associations.

SBIC Digest, U.S. Sma11 Business Administration, Washington, D.C., February 1979.

"SEC Help for Small Companies," Business Week, May 7, 1979.

"Second-Hand Solar Energy," Dennis Hayes, The Washington Post, February 26, 1978.

"Simplified Registration and Reportive Requirements for Small Issurers, Securities and Exchange Commission," Federal Register, Vol. 43, No. 51, March 15, 1978. 
Small Business and Innovation, A Report of an SBA Office of Advocacy Task Force, Office of Chief Counsel for Advocacy, U.S. Small Business Administration, Washington, D.C., May 1979.

Small Enterprise in the Economy, U.S. Sma11 Business Administration, Washington, D.C., June 1978.

The Solar Energy Development Bank Act, Hearings before the Subcommittee on Domestic Monetary Policy of the Committee on Banking, Finance and Urban Affairs, House of Representatives, H.R. 7800, 95th Cong., 2nd Sess., Apri1. 25, 26, 27, 1978.

"Some Comments on Market Penelration, Innovation' and Learning. The Case For Solar Technolngy," Inhri $W$, Herbert, Technological Forecasting and Social Clarige 14, 259-261, 1979.

Statement of Reid W. Dennis, Chairman, National Venture Capital Association, before the U.S. Senate Select Committee on Small Business, May 22, 1979.

The Stock Market and The Economy, Barry Bosworth, Brooking's papers on Economic Activity, Wasinington, D.C., 1975.

A Study of Fixed Capital Requirements of the U.S. Business Economy 19711978, U.S. Bureau of Economic Analysis, Washington, D.C., 1975.

Survey of Current Business, U.S. Department of Commerce, Bureau of Economic Analysis, Washington, D.C., February 1979.

Tax Policy and Capital Formation, Joint Committee on Taxation, Washington, D.C., Apri1 1977.

Tax Policy, Investment and Economic Growth, Securities Industry Association, New York, March 1978.

"The Transformation of Investment Banking," Samuel L. Hayes, III, Harvard Business Review, Vol. 57, No. 1, Harvard University, Boston, Massachusetts, January-February 1979.

"Use of Wind Mills is on the Rise, Held Partly by Higher Cattle Prices," Wal1 Street Journal, June 14, 1979.

"Venture Capital Comes Rar.k," Newsweek, June 1, 1979.

"Venture Capital Investment," Stanley M. Rubel, in Sumner N. Levine (ed.), Financial Analysts Handbook I: Methods, Theory and Portfol io Management, Dow Jones - Homewood, Ill inois, 1975.

"Venture Capital is Plentiful Once More, Partly Due to Changes in Capital Gains Tax," Wall Street Journal, June 15, 1979. 
What Depressed the Consumer? The Household Balance Sheet and the 1973-75 Recession, Frederic S. Mishkin, Brooking's papers on Economic Activity, Washington, D.C., 1977.

"Why We Must Act Now," Newsweek, July 16, 1979.

"Wind Power," The Congressional Record, No. 93-39, August 7, 1974. 